\title{
INFLUENZA VAKCINÁCIÓS MAGATARTÁS ÉS BEFOLYÁSOLÓ TÉNYEZŐINEK VIZSGÁLATA A SZEGEDI TUDOMÁNYEGYETEMEN
}

\author{
INVESTIGATION OF INFLUENZA VACCINATION BEHAVIOR AND ITS \\ INFLUENCING FACTORS AT THE UNIVERSITY OF SZEGED
}

\author{
VEZÉR TÜNDE1, MÜLLER ANNA', LUKÁCS ANITA', BORSÁNYI FRUZSINA², \\ D. KIS NÓRA ${ }^{3}$, HALÁPI BERNADETT4, KATONA CSILLA4, PAULIK EDITT \\ 'SZTE ÁOK Népegészségtani Intézet; Szeged \\ 2Jász-Nagykun-Szolnok Megyei Hetényi Géza Kórház-Rendelőintézet; Szolnok \\ 3Bács-Kiskun Megyei Oktatókórház; Kecskemét \\ 4SZTE Informatikai és Szolgáltatási Igazgatóság; Szeged
}

DOI: https://doi.org/10.29179/EgTud.2019.3-4.3-31

\begin{abstract}
Összefoglalás
Bevezetés: Becslések szerint az influenza évente 4 millió súlyos - tüdő-, agyhártya- és szívizomgyulladással járó - megbetegedést és 300-600 ezer halálesetet okoz világszerte. A WHO influenza immunizációs stratégia célja 2020-ra fokozni a vulnerábilis populáció és az őket veszélyeztetők védelmét. Ismert, hogy hazánkban az egészségügyi dolgozók influenza átoltottsága 2010 óta csökken, és messze elmarad a nemzetközi (70\%), esetenként a magyar (40\%) ajánlásoktól is. Ugyanakkor a kötelező szakmai gyakorlatuk során az aktív betegellátásban tevékenykedő tanulók, hallgatók hasonló adatai nem ismertek, ezzel kapcsolatos reprezentatív hazai kutatások nem történtek.
\end{abstract}

\begin{tabular}{lll}
\hline EGÉSZSÉGTUDOMÁNY & 2019;63(3-4): 3-31. & $\begin{array}{l}\text { Levelezési cím/Correspondence: } \\
\text { VEZÉR TÜNDE }\end{array}$ \\
HEALTH SCIENCE & & Department of Public Health, Faculty of Medicine, \\
Közlésre érkezett: & 2020. január 15. & University of Szeged; \\
Submitted: & 15 January 2020 & Dóm tér 10.6720 Szeged, Hungary; \\
Elfogadva: & 2020. január 30. & Phone: (36-62) 545-119; \\
Accepted: & 30 January 2020 & E-mail: vezer.tunde@ @ed.u-szeged.hu \\
& &
\end{tabular}


A kutatás célja a Szegedi Tudományegyetemen ápolt és influenza fertőzésre fokozottan fogékonyak elláááát végző egészségügyi dolgozók és hallgatók influenza oltási magatartásának megismerése és a szokásokat meghatározó tényezők azonosítása.

Anyag és módszerek: A keresztmetszeti epidemiológiai vizsgálat során az adatgyüjtés saját fejlesztésü, anonim, elektronikus önkitöltős kérdőívvel történt. Az adatelemzést leíró statisztikai módszerek alkalmazásával, SPSS szoftverrel végeztük.

Eredmények: A vizsgálatban résztvevő 100 dolgozó és 291 hallgató 92-94\%-a helyes ismeretekkel rendelkezik az influenzáról, 80-85\% tudja, kik tartoznak a veszélyeztetettek közé, azonban 4\% nem ismeri veszélyeztető rizikócsoportba tartozását. A megkérdezettek négyötöde egyetért azzal, hogy a leghatékonyabb megelőzési mód a védőoltás, és bár 57-83\%-nak orvos, asszisztens, gyógyszerész stb. ajánlotta annak felvételét, a közvetlen betegellátásban tevékenykedő dolgozók 38,5\%-a, míg a hallgatók 69,4\%-a sosem volt oltva, és ezek 55\%-a, illetve 31\%-a ezután sem kíván élni ezzel a lehetőséggel. 62-64\% egyetért a vakcina biztonságosságával, ugyanakkor a dolgozók 55\%-a és a hallgatók 39\%-a állítja, hogy az oltóanyag influenzát okozhat. A valaha oltottak többsége a központilag biztosított, térítésmentes vakcinát preferálja és egyetért a magas (legalább 70\%-os) dolgozói és hallgatói átoltottság szükségességével, de csak 2/3-uknak lényeges saját immunizáltsága. Az oltatlanok oltás elutasításának oka 39-42\%-ban a veszélyeztetettség tudatának hiánya, 22-24\%-ban az egyéb megelőzési módszerek előnyben részesítése és 15-20\%-ban az oltás kevésbé fontosnak tartása. A rendszeresen oltottak döntését tudományos ismereteik, korábbi pozitív vakcinációs tapasztalataik, az oltóanyag hatékonyságába vetett bizalom, továbbá saját és családtagjaik egészségének védelme motiválja. Az oltást követő nemkívánatos esemény erős visszatartó erő lehet. Kiemelendő, hogy a hallgatók többsége a 2017/2018. évi szezon során nem tudott térítésmentes oltásra jogosultságáról.

Következtetések: Eredményeink alapján lehetőség nyílik az influenza vakcinációs szereplök (munkáltató, oltóorvos, oltandók) immunizációs érdekeltségének, felelősségtudatának, kommunikációjának, valamint oltástudatosságának és motivációjának fokozására, végső soron a térítésmentes oltásra jogosultak átoltottsági arányának kedvező irányú megváltoztatására.

Kulcsszavak: influenza, vulnerábilis csoportok, prevenció, védőoltás, influenza oltóanyagok

Levelező szerző: Vezér Tünde, SZTE ÁOK Népegészségtani Intézet, 6720 Szeged, Dóm tér 10.; tel: +36 62 545-119; e-mail: vezer.tunde@med.u-szeged.hu.

\section{Abstract}

Introduction: According to estimations, influenza can cause worldwide 4 million serious illnesses (leading to pneumonia, meningitis and myocarditis) and 300-600 thousand deaths every year. The WHO Flu Immunization Strategy aims at improving the protection of the vulnerable population and those putting them at risk of being infected by 2020. In Hungary, the number of vaccinated health care professionals has been dwindling since 2010, it is also far from the international (70\%) and in some instances the Hungarian (40\%) recommendations. On the other hand, similar data of students working in active patient care during their compulsory professional practice are unknown, and no domestic research has been conducted so far. 
The aim of this study is to understand the vaccination behaviour, and to identify the factors that determine these habits, of healthcare workers (HCWs) and students who attend patients that are highly susceptible to influenza infection and are hospitalized at the University of Szeged.

Material and Methods: The cross-sectional epidemiological study was conducted by self-developed, anonymous, electronic self-administered questionnaires. Data analysis was performed by using descriptive statistical methods, by means of the SPSS software.

Results: Out of the $100 \mathrm{HCWs}$ and 291 students surveyed, 92-94\% had the right knowledge about flu, 80$85 \%$ knew who the endangered ones are, however $4 \%$ did not know whether he/she belonged to the vulnerable group.

Four-fifths of respondents agreed that vaccination is the most effective form of prevention. Albeit 57-87\% was advised by a doctor, assistant, pharmacist or other professional to get vaccinated, $38.5 \%$ of employees working in direct patient care and $69.4 \%$ of the students have never been vaccinated, and $55.31 \%$ out of them still do not want to take advantage of this opportunity. $62 \%$ to $64 \%$ of the participants agreed on the safety of the vaccine, however $55 \%$ of the workers and $39 \%$ of students stated that the vaccine can cause influenza.

Most people who have ever been vaccinated preferred the centrally provided, free vaccine and agreed with the necessity of high level (at least 70\%) vaccination coverage rate of workers and students, but their own immunization was important to only $2 / 3$ of them. Reasons for the rejection of vaccination among nonvaccinated were lack of vulnerability awareness in $39-42 \%$ of the cases, $22-24 \%$ preferred other prevention methods, and 15-20\% considered vaccination less important. The decision of the regularly vaccinated people was motivated by their scientific knowledge, their previous positive vaccination experience, their confidence in the effectiveness of the vaccine and their own and their family members' health protection. The unwanted outcome caused by vaccination can be a strong deterrent. It should be noted that the majority of students had no information of their eligibility for free vaccination during the 2017/2018 flu season.

Conclusions: Our results can provide an opportunity for further enhancing the immunization interest, responsibility, communication, vaccine awareness and motivation of those participating in the process of flu vaccination (employers, vaccinators, vaccinees) and ultimately for a favourable change in the vaccination rate of those eligible for free vaccination.

Keywords: influenza, vulnerable groups, prevention, vaccination, flu vaccines

\section{Bevezetés}

Az influenza védőoltással megelőzhető, a mérsékelt éghajlati övezetben őszi-téli szezonalitást mutató légúti fertőző betegség, mely a 2018 végén publikált modellszámítások szerint (1) világszerte évente 4 millió súlyos (tüdő-, agyhártya-, szívizomgyulladással járó) megbetegedést és 291-600 ezer (légzőszervi szövődmény miatt bekövetkező) halálesetet okozhat. A téli influenzajárványok az európai populáció megközelítően 10-30\%-át érintik, melyek a cirkuláló domináns influenzavírus szero- és 
szubtípustól függően 25-100 millió fertőzéssel, 3,5 millió kórházi felvétellel, 2,2 millió súlyos szövődménnyel és 40-170 ezer halálesettel állhatnak összefüggésben. Az Európai Unióban/Európai Gazdasági Térségben (European Union/European Economic Area; EU/EEA) a fertőző betegségteher közel 30\%-át az influenza adja (2).

A betegség és súlyos légzőszervi szövődményei elsősorban a legkedvezőtlenebb anyagi háttérrel rendelkezöket és a legidősebbeket sújtják. A 65 évesnél idősebbek köréből kerül ki a hospitalizáltak 70-80\%-a, valamint a letális kimenetelü megbetegedések több mint 90\%-a. A halálozás valószínüsége háromszorosra nő krónikus betegség pl. diabetes mellitus egyidejű fennállása esetén $(3,4,5)$. Az Európai Betegségmegelőzési és Járványvédelmi Központ (European Centre for Disease Prevention and Control; ECDC) becslései szerint az idő előtti halálozás átlagosan közel 40 ezerre tehető minden évben az EU/EEA tagállamaiban (6). Az influenza-cirkulációval egyidejüleg észlelt megnövekedett többlethalálozás erősen megterheli a kórházi ellátást, valamint az egészségügyi és szociális szektorok erőforrásait a legtöbb EU/EEA tagországban (7). Ezen túlmenően a munkahelyi és oktatási rendszerből történő hiányzások és a termelékenység csökkenése direkt vagy indirekt módon megközelítőleg 6-14 billió eurós terhet rónak az EU éves költségvetésére (7). Magyarországon az elmúlt évek alacsony influenza aktivitása miatt az influenza-szerü tünetekkel orvoshoz fordulók becsült száma 200-300 ezer fö/év, az influenza pozitivitási arány 8-63\% között mozgott, az egyes megyék becsült kumulatív morbiditása pedig 1-5\% volt (8).

A nemzetközi influenza eliminációs stratégiák, irányelvek $(3,9,10)$ célkitűzése 2020-ra csökkenteni a kórképnek tulajdonítható populációs szintü népegészségügyi hatásokat, károkat. Ezért fontos feladat a vulnerábilis populációba tartozók (pl. idősek, várandósok, krónikus betegségben szenvedők) és az őket veszélyeztető egészségügyi ellátó rendszerben tevékenykedők influenza elleni védelmének fokozása. A betegség és súlyos szövődményeinek megelőzésére szolgáló leghatékonyabb népegészségügyi beavatkozás a vakcináció $(11,12)$.

A 2017/2018. évi influenza szezonban 29 EU/EAA tagállamban ajánlották az influenza oltás felvételét az egészségügyi dolgozóknak, melyek közül 23-ban (pl. Skócia, Magyarország) valamennyi, míg ötben (Belgium, Norvégia, Portugália, Szlovákia és Svédország) csupán egyes (pl. járóbeteg-, fekvőbeteg- és tartós ápolási) osztályokon tevékenykedőknek. További öt országban (pl. Anglia, Wales területén) csak a betegekkel közvetlenül érintkező, illetve a „betegellátási frontvonalba” tartozó egészségügyi 
dolgozóknak került felajánlásra az oltás, bár utóbbi esetben a kórházak valamennyi alkalmazottjuk részére biztosították azt. Dániában nem volt nemzeti javaslat az egészségügyi dolgozók oltására, azonban a legtöbb régió és település ingyenes oltást kínált számukra. Valamennyi tagállamban önkéntesen (azaz szabad elhatározásból) történt az egészségügyi dolgozók szezonális influenza oltása, elmulasztása nem vont szankciót maga után (13).

A 2009/2010. évi - 2014/2015. évi szezonokban az egészségügyi dolgozók átoltottsága az adatot szolgáltató 17 EU tagállamban széles határok közt változott (570,1\%), de legtöbbjük messze elmaradt az Egészségügyi Világszervezet (World Health Organization; WHO) és EU/EEA (legalább 70\%), esetenként a magyar (40\%) ajánlásoktól (1. ábra). A 17 ország átoltottsági arányának medián értéke a 8 influenza szezonban $26,9 \%$ volt, melynél a hazai értékek kedvezőbbnek bizonyultak (29,2-53,6\%; az átoltottsági ráta mediánja 38,7\%) (9). A 2015/2016. évi - 2017/2018. évi szezonokban az ECDC-nek jelentő 12 EU/EEA ország többségének átoltottsága még mindig alacsony értéken állt (15,6-63,2\%; vakcinációs ráta medián a 2016/2017. évi szezon során 30,2\%) (2. ábra; 13). Hazánkból ebben a megfigyelési periódusban 28,1-28,1-31,2\% átoltottsági medián értékeket jelentettek.

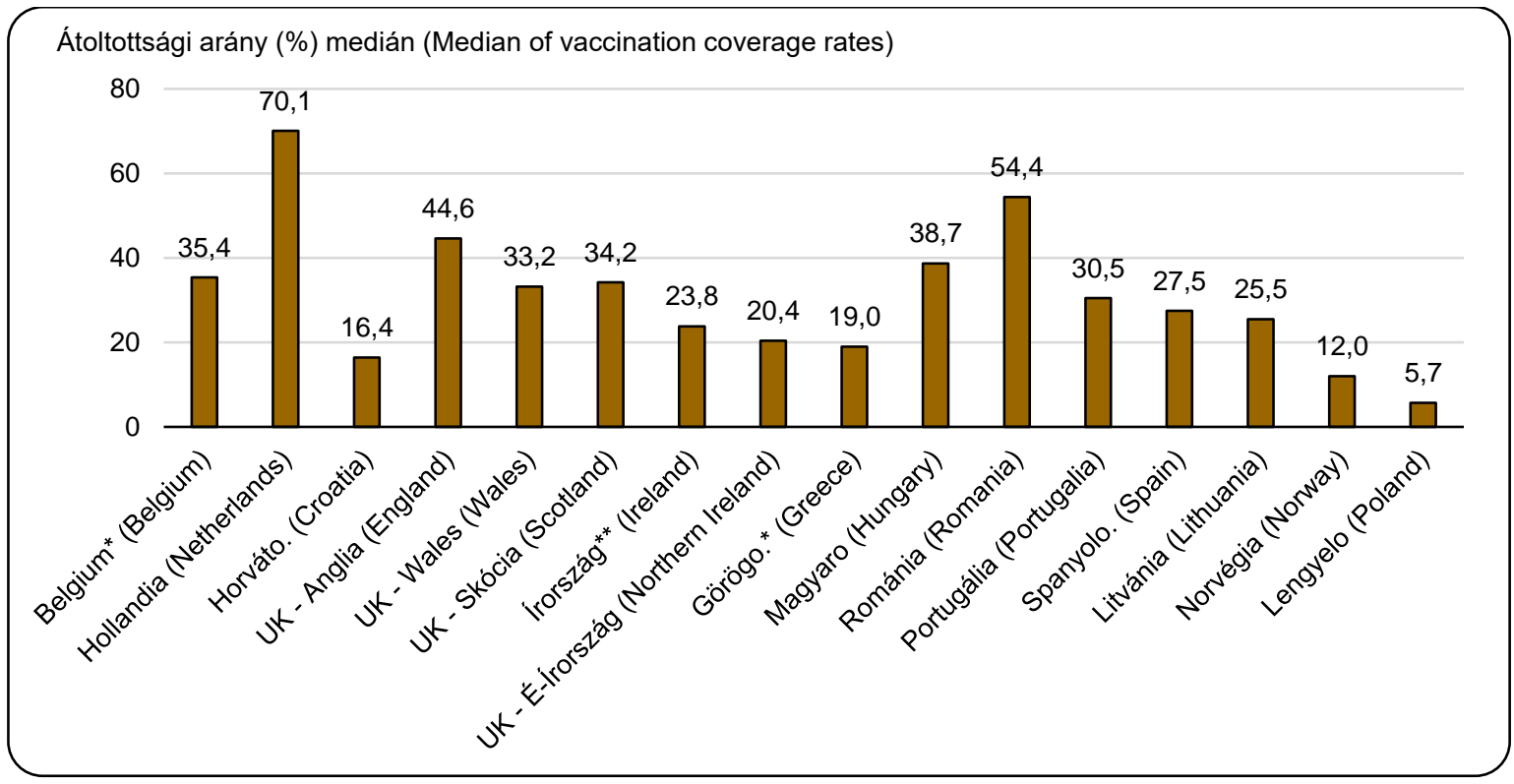

1. ábra Szezonális influenza oltás az EU tagállamokban 2007-2015 között. Adatforrás: (9)

Figure 1 Seasonal flu vaccination in EU/EEA, 2007-2015 


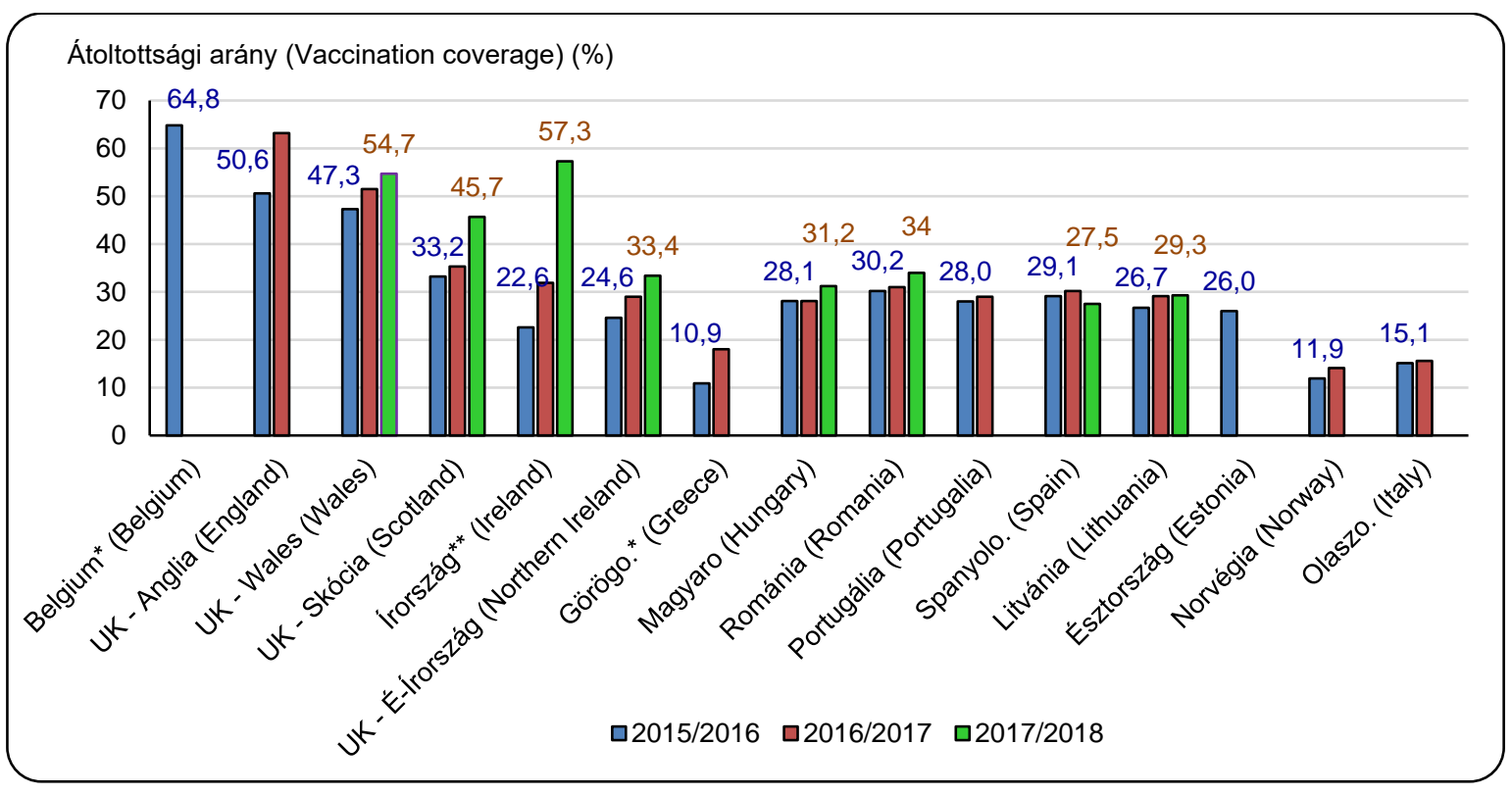

2. ábra Szezonális influenza oltás az EU tagállamokban 2015-2018 között. Adatforrás: (13) Jelmagyarázat: *: egészségügyi dolgozók a járóbetegellátásban; **: egészségügyi dolgozók csak az akut ellátást végző kórházakban

Figure 2 Seasonal flu vaccination in EU/EEA, 2015-2018

Legends: *: healthcare workers (HCWs) in out-patient healthcare settings; **: HCWs in acute hospitals only

Magyarországon 1998 óta a munkáltató köteles a foglalkozás-egészségügyi szolgálat közremüködésével kockázatbecslést és -kezelést végezni a biológiai tényezők hatásának kitett munkavállalók egészsége védelmében (14). A védőoltással megelőzhető foglalkozási betegségek (pl. influenza) esetén biztosítania kell a kockázatnak kitett és más rizikócsoportokat is veszélyeztető munkakörökben tevékenykedők (munkavállalók, tanulók, hallgatók) számára a szükséges védőoltásokat (15). Emellett a hazai védőoltás módszertani ajánlások szerinti kockázati csoportba tartozók számára évenként 1,3 millió térítésmentes inaktivált trivalens szezonális influenza oltóanyag áll rendelkezésre. Ezen belül az egészségügyi dolgozók (2010 óta folyamatosan csökkenő) átoltottsági adatai ismertek, azonban a közvetlen betegellátásban is tevékenykedő egészségügyi képzettséget adó oktatási intézmények tanulóiról, hallgatóiról nem állnak rendelkezésre hasonló adatok. Körükben az influenza vakcinációs attitüdöt befolyásoló tényezők sem ismertek.

Ezért célunk volt a Szegedi Tudományegyetem (SZTE) intézeteiben ápolt, influenza fertőzés szempontjából a fokozottan veszélyeztetett személyek aktív betegellátásában résztvevő SZTE egységek és oktató karok dolgozói, illetve hallgatói 
körében megismerni a kórképpel és szövődményeivel kapcsolatos tudást, prevenciós ismereteket, oltási szokásokat (pl. vakcinációs hajlandóságot, motiváló/demotiváló tényezőket). Ezen túlmenően összevetni a különböző vakcinációs attitüdöt mutatók átoltottsági arányát, valamint felmérni az oltási attitüdöt meghatározó és/vagy befolyásoló objektív és szubjektív faktorokat (pl. félelem, bizalom, információ) és rizikóállapotokat, tényezőket (pl. krónikus betegség fennállása, >60 éves kor).

\section{Anyagok és módszerek}

A keresztmetszeti epidemiológiai vizsgálat 2018. április-május hónapban a SZTE Általános Orvostudományi Kar (ÁOK) Klinikai Központ 8 betegellátó egységének és 3 oktató (Gyógyszerész-, Fogorvos-, valamint Egészségtudományi és Szociális Képzési; GYTK, FOK, ETSZK) karának dolgozói, továbbá a 4 képző (ÁOK, GYTK, FOK, ETSZK) karának magyar nyelvü képzésén (nappali és levelező tagozaton) tanulmányokat folytatók körében került lefolytatásra. A kutatás célcsoportja a betegellátásban tevékenykedő 1300 egészségügyi dolgozó, a 4 oktató karon 400 dolgozó, valamint a graduális és posztgraduális képzésben a kötelező gyakorlatokon az ellátottakkal kapcsolatba kerülő 3200 egyetemi hallgató. A vizsgálatban való részvétel kritériuma a cselekvőképes 18 éven felüli életkor, valamint a tájékoztatás megértését és elfogadását követő beleegyezés volt. $\mathrm{Az}$ adatgyüjtés saját fejlesztésü, anonim, on-line (EvaSys) önkitöltős kérdőív felhasználásával történt.

A kutatás tervezett célcsoportját képező - az elektronikus kérdőívet megkapó 5400 fö közül csupán 428 személy (127 dolgozó és 301 hallgató) olvasta el a vizsgálati tájékoztatót, mellyel 1 hallgató nem értett egyet, 21 dolgozó és 5 hallgató jelezte, hogy nem kíván a vizsgálatban részt venni, további 3 dolgozó pedig nem adta a beleegyezését. A kérdőívet így összesen 103 dolgozó és 295 hallgató töltötte ki, melyekből egyes lényeges demográfiai adatok (nem, életkor, lakóhely) hiánya miatt 3 dolgozói és 4 hallgatói válaszadás kizárásra került. A statisztikai értékelés 391 fö adatai alapján történt, a válaszadási arány 7,2\% (dolgozói 5,9\%; hallgatói 9,1\%) volt.

A kérdőív szocio-demográfiai jellemzőkkel, egészségi állapottal, influenza betegséggel, oltottsági státusszal, oltási hajlandósággal és attitűddel, valamint az influenza oltással kapcsolatos 7 fö kérdésblokkot tartalmazott. 
A szocio-demográfiai kérdések között szerepelt az életkor, a nem, a lakóhely település típusa, a családi állapot, a legmagasabb befejezett iskolai végzettség, a 18 éven aluli személlyel együtt élés, a saját/család anyagi helyzet megítélése. Az anyagi helyzet megkérdezettek általi minősítése 1-5-ig terjedő válaszskálán történt (1=nagyon rossz, 2=rossz, 3=közepes, 4=jó, 5=nagyon jó), mely alapján átlagpontokat számoltunk a statisztikai elemzéshez. Az influenza fertőzésveszély lehetőségére vonatkozó információkat a SZTE karokon, illetve intézményekben tanulás/munkavégzés helyére, utolsó 3 éves tartamára, valamint az aktív betegellátásban történő részvételre és annak intenzitására (soha, ritkán, folyamatosan) vonatkozóan gyüjtöttük.

$\mathrm{Az}$ egészségi állapottal kapcsolatos mutatókat válaszskálán minősítették a megkérdezettek, melybe beletartozott az egészség (1=nagyon rossz, 2=rossz, 3=kielégítő, 4=jó, 5=nagyon jó) és az egészségért érzett felelősség/aktív cselekvés mértékének (1=semmit, 2=keveset, 3=sokat, 4=nagyon sokat) megítélése; valamint az utóbbi 3 évre vonatkozóan a saját (és a közös háztartásban élők) influenzára hajlamosító krónikus betegségeinek megjelölése.

$\mathrm{Az}$ influenzával kapcsolatos tudásszint felmérése egyrészt a betegségre (a rizikócsoportokra, az azokat veszélyeztetőkre, a hajlamosító tényezőkre, a tünetekre és a szövődményekre) vonatkozó többszörös választásokra, másrészt a kórkép epidemiológiai jellemzőivel (kórokozó, terjedési mód, kimenetel, immunitás, megelőzés) kapcsolatos igazhamis állításokra adott helyes válaszok pontozása, illetve tudás-skála alapján történt.

A többszörös választás esetén a tudásszint meghatározásához helyes válaszadási (score) pontokat számoltunk, melyhez az egy kérdésben felsorolt tényezők válaszadói minősítését (igaz, hamis) két kategóriába, azaz „tudta” (igaz állításra: igaz; hamis állításra: hamis), illetve „nem tudta” (igaz állításra: hamis; hamis állításra: igaz) soroltuk. A „tudta” +1 helyes válaszpontot, míg a „nem tudta” 0 pontot jelentett. A többszörös választásban felsoroltak mindegyikének „tudása” a maximálisan adható, míg azok „nem tudása” a minimálisan adható (score $=0$ ) helyes válasz pontértéket jelentette. Az adott és a maximálisan adható helyes válaszok pontszámának aránya a válaszadó 0-100\% ismeretszintjéről (vagy éppen annak hiányáról) nyújtott tájékoztatást a feltett kérdés esetén.

Az influenza epidemiológiai jellemzőivel kapcsolatos tudás méréséhez a 9 igazhamis állításra adott válaszokat (igaz, hamis, nem tudom) a statisztikai vizsgálathoz két kategóriába, azaz „tudja” (igaz állításra: igaz; hamis állításra: hamis), illetve „nem tudja” (nem tudom; igaz állításra: hamis; hamis állításra: igaz) vontuk össze. Az egyes állítások 
ismerete alapján 0-9-ig terjedő pontértéket (tudás-skálát) határoztunk meg ( $0=$ egyik állítást sem tudja; 9=mindegyik állítást helyesen tudja).

Az átoltottság mértékének megismeréséhez adatgyüjtés történt az oltást ajánló személyekre, az oltási szokásokra (a valaha; azon belül a felmérést megelőző utolsó 3 évi azaz a 2014/2015 - 2016/2017. közötti - és a legutolsó - azaz a 2017/2018. évi szezonban történő oltottságra), az oltás elmaradás okaira, a jövőben történő vakcináció valószínűségére, a legjellemzőbb oltóanyag beszerzési módra vonatkozóan. A kutatást megelőző utolsó 3 évi oltási gyakoriságot az alábbi 5 válaszskála alapján minősítették a megkérdezettek: nem emlékszem, de korábban már voltam oltva; egyszer sem, de korábban már voltam oltva; 1-2-szer, azaz időnként oltatom magam; rendszeresen, minden évben. Az elemzések során a válaszokból 2 kategóriát képezve, azaz „több mint 3 éve oltott” (nem emlékszem, de korábban már voltam oltva; egyszer sem, de korábban már voltam oltva), illetve „kevesebb mint 3 éve oltott” (1-2-szer, azaz időnként oltatom magam; rendszeresen, minden évben) elemeztük az oltásfelvétel általános jellemző gyakoriságát, illetve fontosnak tartását. Az aktuálisan jellemző oltási gyakoriság megismeréséhez ugyanennek az 5 minősítésnek másik két kategóriába sorolásával, azaz „időnként oltott” (nem emlékszem, de korábban voltam már oltva; egyszer sem, de korábban voltam már oltva; 1-2-szer, azaz időnként oltatom magam) és „rendszeresen oltott" (rendszeresen, minden évben) kerültek a válaszok elemzésre.

Az oltási hajlandóság és magatartás mérése többszörös választással történt, melyben az időnként és rendszeresen oltottak oltásfelvételi döntését motiváló tényezőkre, illetve az influenza immunizálásban sosem részesültek oltás elutasításának okaira kérdeztünk rá. Az oltási szokások további megismerésére az egyes (segítő vagy visszatartó) tényezőket tartalmazó állításokat 1-5 válaszskálán minősítették a megkérdezettek: egyáltalán nem fontos, kevésbé fontos, közepesen fontos, fontos, nagyon fontos. Az elemzések során a válaszokat két kategóriába vontuk össze, azaz „fontos” (nagyon fontos, fontos), illetve „nem fontos” (közepesen/kevésbé/egyáltalán nem fontos).

Az influenza védőoltással kapcsolatos információs források (egészségügyi, illetve nem egészségügyi végzettségű személy, egyéb) hitelesnek tartását a válaszolók szintén 1-5 válaszskálán, az alábbiak szerint minősítették: egyáltalán nem hiteles, inkább nem hiteles, közepesen hiteles, inkább hiteles, leginkább hiteles. Az elemzések során a válaszokat két kategóriába csoportosítottuk, azaz „hiteles” (leginkább/inkább hiteles), illetve „,nem hiteles” (közepes/inkább nem/egyáltalán nem hiteles). A védőoltás felvételével kapcsolatos 
döntés során figyelembe vett kommunikációs csatornák megfelelőségét hasonlóan minősítették a válaszolók: egyáltalán nem megfelelö, inkább nem megfelelö, közepesen megfelelő, inkább megfelelő, leginkább megfelelő). Az elemzésekhez a válaszokat két kategóriába vontuk össze, azaz „megfelelő” (leginkább/inkább megfelelő), illetve „nem megfelelő" (közepesen/inkább nem/egyáltalán nem megfelelő).

Az influenza elleni védőoltással kapcsolatos helyes és hamis állításokkal való egyetértés szintén 1-5 válaszskálán történt: egyáltalán nem ért egyet, inkább nem ért egyet, nem tudom, inkább egyetért, teljesen egyetért. A statisztikai értékeléshez a válaszokat két új kategórába soroltuk: „kellően tájékozott” (inkább/teljesen egyetért), illetve „nem kellően tájékozott" (nem tudom, inkább/egyáltalán nem ért egyet).

A statisztikai elemzéseket IBM SPSS 24.0 programmal végeztük. A mennyiségi és minőségi adatok jellemzésére egyszerü leíró statisztikákat (gyakoriság, átlag) alkalmaztunk. Normalitás vizsgálatot követően az átlagok összehasonlítása kétmintás tpróbával (Welch) és egyutas variancia analízissel (ANOVA), a kapcsolatok vizsgálata Khi ${ }^{2}$ (Pearson, illetve Fisher egzakt) teszttel történt. Az eredmények értékeléséhez 5\%-os szignifikancia szintet $(\mathrm{p}<0,05)$ használtunk.

A vizsgálatot a SZTE Szent-Györgyi Albert Klinikai Központ Humán Orvosbiológiai Intézményi és Regionális Kutatásetikai Bizottsága engedélyezte (engedélyszám: 4153).

\section{Eredmények}

\section{Szocio-demográfiai jellemzők és egészségi állapot}

A kérdöíves adatgyüjtés után - a módszertani részben leírt tisztítást követően - 100 dolgozó ( 75 nő, 25 férfi) és 291 hallgató (224 nő, 67 férfi) adatai kerültek statisztikai feldolgozásra.

A dolgozók átlagéletkora 46,3 $\pm 13,7$ év, míg a hallgatóké $24,4 \pm 6,1$ év volt. A megkérdezett 391 személy közül az influenza fertőzés szempontjából fokozottan fogékony csoportba tartozó 60 éves vagy annál idősebb korúak 2,8\%-ot, az utóbbi 3 évben krónikus betegséggel kezeltek 11-12\%-ot, míg a 18 évesnél fiatalabb családtaggal élők 30\%-ot tettek ki. A krónikus betegséggel kezeltek $80-90 \%$-a részt vett a betegellátásban. A dolgozók 89\%-a felsőfokú (BSc, MSc, OKJ), 9\%-a középfokú (szakközépiskola/technikum, gimnázium), 1\%-a szakmunkásképző/szakiskolai legmagasabb befejezett iskolai végzett- 
ségü volt, míg a hallgatók közel 9\%-a egyetemi/föiskolai 12\%-a közép- és 79\%-a alapfokú (általános iskola, szakmunkásképző/szakiskola) végzettséggel rendelkezett (I. táblázat).

A dolgozók 97\%-a és a hallgatók 71,4\%-a az utóbbi három évben a SZTE munkatársa, illetve hallgatója volt. A hallgatók 41,6\%-a (121 fö) az SZTE ÁOK-n, 38,5\%-a (112 fö) az ETSZK-n, 14,4\%-a (42 fö) a GYTK-n és 5,5\%-a (16 fö) a FOK-n folytatott tanulmányokat. A 291 fö közel 3/4 része nappali, 1/4-e levelező tagozaton tanult. Posztgraduális MSc, illetve felsőoktatási szakképzésben részesült közülük 3,5\%, illetve 5\%.

\section{I. táblázat Szocio-demográfiai alapadatok}

Table I Baseline socio-demographic characteristics

\begin{tabular}{|c|c|c|c|c|}
\hline \multicolumn{3}{|l|}{$\begin{array}{l}\text { Adatok } \\
\text { Data }\end{array}$} & $\begin{array}{l}\text { Dolgozók } \\
\text { HCWs } \\
(\mathrm{n}=100)\end{array}$ & $\begin{array}{c}\text { Hallgatók } \\
\text { Students } \\
(\mathrm{n}=291)\end{array}$ \\
\hline \multirow{2}{*}{ Nem; Gender } & \multirow{2}{*}{\multicolumn{2}{|c|}{$\begin{array}{l}\text { Férfi; Male } \\
\text { Nö; Female }\end{array}$}} & $25,0 \%(25)$ & $23,1 \%(67)$ \\
\hline & & & $75,0 \%(75)$ & $76,9 \%(224)$ \\
\hline Életkor; Age & \multicolumn{2}{|c|}{ Átlag $\pm \mathrm{SD} ; \mathrm{Mean} \pm \mathrm{SD}$} & $46,3 \pm 13,7$ & $24,4 \pm 6,1$ \\
\hline \multirow{2}{*}{$\begin{array}{l}\text { Korcsoportok } \\
\text { Age groups }\end{array}$} & \multicolumn{2}{|c|}{$\geq 60$ éves; $\geq 60$ years of age } & $11,0 \%(11)$ & $0,0 \%(0)$ \\
\hline & \multicolumn{2}{|c|}{$<60$ éves; $<60$ years of age } & $89,0 \%(89)$ & $100 \%(291)$ \\
\hline \multirow{6}{*}{$\begin{array}{l}\text { Legmagasabb } \\
\text { befejezett iskolai } \\
\text { végzettség } \\
\text { Highest completed } \\
\text { education }\end{array}$} & $\begin{array}{l}\text { Alapfokú iskolai } \\
\text { végzettség }\end{array}$ & Nö (F) & $1,0 \%(1)$ & $59,8 \%(174)$ \\
\hline & $\begin{array}{l}\text { Primary } \\
\text { education* }\end{array}$ & Férfi (M) & $0,0 \%(0)$ & $19,2 \%(56)$ \\
\hline & $\begin{array}{l}\text { Középfokú } \\
\text { iskolai }\end{array}$ & Nő (F) & $7,0 \%(7)$ & $10,3 \%(30)$ \\
\hline & $\begin{array}{l}\text { végzettség } \\
\text { Secondary } \\
\text { education } * *\end{array}$ & Férfi (M) & $2,0 \%(2)$ & $1,7 \%(5)$ \\
\hline & $\begin{array}{l}\text { Felsőfokú iskolai } \\
\text { végzettség }\end{array}$ & Nő (F) & $66,0 \%(66)$ & $6,5 \%(19)$ \\
\hline & $\begin{array}{l}\text { Tertiary } \\
\text { education } \\
\text { level*** }\end{array}$ & Férfi (M) & $23,0 \%(23)$ & $2,1 \%(6)$ \\
\hline \multicolumn{3}{|c|}{$\begin{array}{l}18 \text { évnél fiatalabbal együtt élők } \\
\text { Living together with under } 18 \text {-year-olds }\end{array}$} & $31,0 \%(31)$ & $29,9 \%(87)$ \\
\hline \multicolumn{3}{|c|}{$\begin{array}{l}\text { Az utolsó } 3 \text { évben krónikus betegségben szenvedők } \\
\text { Persons suffering from chronic disease in the last } 3 \\
\text { years }\end{array}$} & $11,0 \%(11)$ & $12,0 \%(35)$ \\
\hline \multicolumn{3}{|c|}{$\begin{array}{l}\text { Aktív betegellátásban tevékenykedők } \\
\text { Persons working in active patient care }\end{array}$} & $96,0 \%(96)$ & $79,4 \%(231)$ \\
\hline \multicolumn{3}{|c|}{$\begin{array}{l}\text { Krónikus betegséggel kezelt betegellátásban résztvevők } \\
\text { Persons working in active care of patients with chronic } \\
\text { illness }\end{array}$} & $9,0 \%(9)$ & $11,7 \%(31)$ \\
\hline
\end{tabular}

Jelmagyarázat: SD: szórás; *: általános iskola 8 osztály, szakmunkásképző/szakiskola; **: szakközépiskola/technikum, gimnázium; ***: OKJ szakképzés, főiskola, egyetem

Legends: SD: standard deviation; F: female; M: male; HCWs: health care workers; *: elementary school 8 classes, vocational training / vocational school; **: vocational secondary school / technical school, high school; ***: non-school vocational training, college, university 
Az anyagi helyzet minősítése (1=nagyon rossz; 5=nagyon jó) során a válaszolók 6,1\%-a (dolgozók 4,9; hallgatók 6,5\%-a) nagyon jó, 46,2\%-a (dolgozók 49,5\%-a; hallgatók 45\%-a) jó, 43,7\%-a (dolgozók 39,8\%-a; hallgatók 45\%-a) közepes, 0,3\%-a (dolgozók 5,9\%-a; hallgatók 3,1\%-a) rossz, míg 3,8\%-a (dolgozók 0\%-a; hallgatók 0,3\%-a) nagyon rossz anyagi helyzetünek vallotta magát. Az anyagi helyzet minősítésének legmagasabb átlag pontszáma a férfi dolgozók és hallgatók körében $(3,60 \pm 0,645 ; 3,60 \pm 0,740)$, míg legalacsonyabb átlag pontértéke a női dolgozók esetében $(3,52 \pm 0,704)$ volt, de a különbség nem volt szignifikáns.

Az egészségi állapot 1-5-ig terjedő válaszskála alapján történt minősítésének (1=nagyon rossz; 5=nagyon jó) átlag pontértéke a férfi hallgatók körében bizonyult a legmagasabbnak $(4,24 \pm 0,698)$, míg legalacsonyabb a férfi dolgozók $(3,92 \pm 0,759)$ esetében volt. Az egészségi állapot legalacsonyabb önértékelési pontszáma 2 (rossz; megkérdezettek 0,5\%-a), a legmagasabb 5 (nagyon jó; megkérdezettek 29,4\%-a) volt. A résztvevők minősítése nem mutatott egymástól szignifikáns eltérést.

Arra a kérdésre, hogy mennyit tehetnek ( $1=$ =semmit; 4=nagyon sokat) az egészségük érdekében, a megkérdezettek 50,4\%-a (197 fö; a dolgozók 40,6\%-a és a hallgatók 53,6\%a) úgy gondolta, hogy nagyon sokat, továbbá 46,8\%-a (183 fö; a dolgozók 69\%-a és a hallgatók 44\%-a) hogy sokat. A vizsgálatban résztvevők 2,8\%-a (11fö) - 4 dolgozó (4\%; nők 1,3\%-a, férfiak 12\%-a) és 7 hallgató (2,4\%; nők 1,3\%-a; férfiak 6\%-a) vélte azt, hogy csak keveset tehet önmaga egészségéért. Az egészségért való aktív cselekvés legkisebb pontértéke 2 (keveset), a legmagasabb 4 (sokat) volt a résztvevők körében. A legmagasabb átlag pontértéket a női hallgatók $(3,54 \pm 0,525)$, míg legalacsonyabbat a férfi dolgozók $(3,20 \pm 0,645)$ értek el; a két csoport felelősségérzetének pontokban kifejezett önminősítése szignifikáns $(\mathrm{p}=0,016)$ eltérést mutatott. A válaszoló dolgozók és hallgatók, ezen belül a nők (dolgozók: $3,41 \pm 0,523$; hallgatók: $3,54 \pm 0,525$ ) egészségükért érzett felelősségtudata közötti eltérés a szignifikancia határán $(\mathrm{p}=0,053 ; \mathrm{p}=0,074)$ volt.

\section{Az influenzával kapcsolatos ismeretek}

A kutatásban résztvevők influenzával kapcsolatos tudása a veszélyeztetett és veszélyeztető populációval, a betegségre hajlamosító tényezőkkel, a tünetekkel és a szövődményekkel 
kapcsolatos többszörös választásokra, valamint igaz-hamis állításokra adott helyes válaszaik alapján került felmérésre.

A legtöbb dolgozó és hallgató helyesen tudta, hogy a 60 éven felüliek, a tartósan ápolt vagy a szalicilát kezelésben részesülő gyermek, a csecsemő- és gyermekotthonban lakók és a várandósok az influenza fertőzés szempontjából fokozott kockázatú csoportba sorolandók, míg a szülőképes korú nők nem. Az 5 lehetséges (4 igaz és 1 hamis) felsorolást tartalmazó, influenza rizikócsoportba tartozás ismeretét felmérö többszörös választásra a hallgatók 47,4\%-a (137 fö) és a dolgozók 37\%-a (37fő), azaz közel minden 2. hallgató és 3. dolgozó adott hibátlan $($ score $=5$ ) választ. 80\%-os tudásszintet (azaz

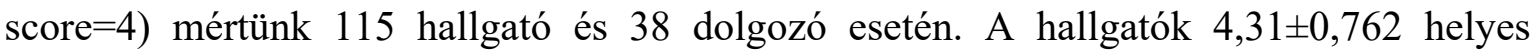
válaszadási átlagpontszámot értek el a maximális ötből, míg a dolgozók átlag score értéke 4,06 $\pm 0,906$ volt. Legmagasabb átlag pontszámot a hallgató nők $(4,37 \pm 0,763)$, míg legalacsonyabbat $(3,8 \pm 1,118)$ a dolgozó férfiak szereztek. A megkérdezettek által adott legkevesebb helyes válaszok száma 2-nek bizonyult 7 fö hallgató és 7 fö dolgozó esetében $(2,4 \%$, illetve $7 \%)$.

Legtöbben (360 fő; a 100 dolgozó 93\%-a - férfiak 88\%-a, nők 94,7\%-a; és a 291 hallgató 91,6\%-a - férfiak 85,1\%-a, nők 93,8\%-a) tudták, hogy a 60 éven felüliek (életkoruktól függetlenül) veszélyeztetettek influenzával. A hallgatók szignifikánsan többen ( $\mathrm{p}=0,044$; azon belül a hallgató férfiak $\mathrm{p}=0,004)$ jelölték meg helyesen, hogy a csecsemö- és gyermekotthonok lakói a rizikócsoportba tartoznak, és közülük többen ismerték, mint a dolgozók, hogy a szülőképes korú nők nem tartoznak a veszélyeztetettek közé ( $\mathrm{p}=0,078$; azon belül a hallgató nők $\mathrm{p}=0,056$ ).

A válaszolók körében legkevésbé volt ismert (315 fö; a dolgozók 75\%-a - férfiak 64\%-a, nők 84\%-a; a hallgatók 82,5\%-a - férfiak 82,1\%-a, nők 82,6\%-a) az egészségügyi intézményekben tartósan ápolt vagy szalicilát kezelésben részesülő gyermekek kockázati csoportba tartozása (3. ábra). 


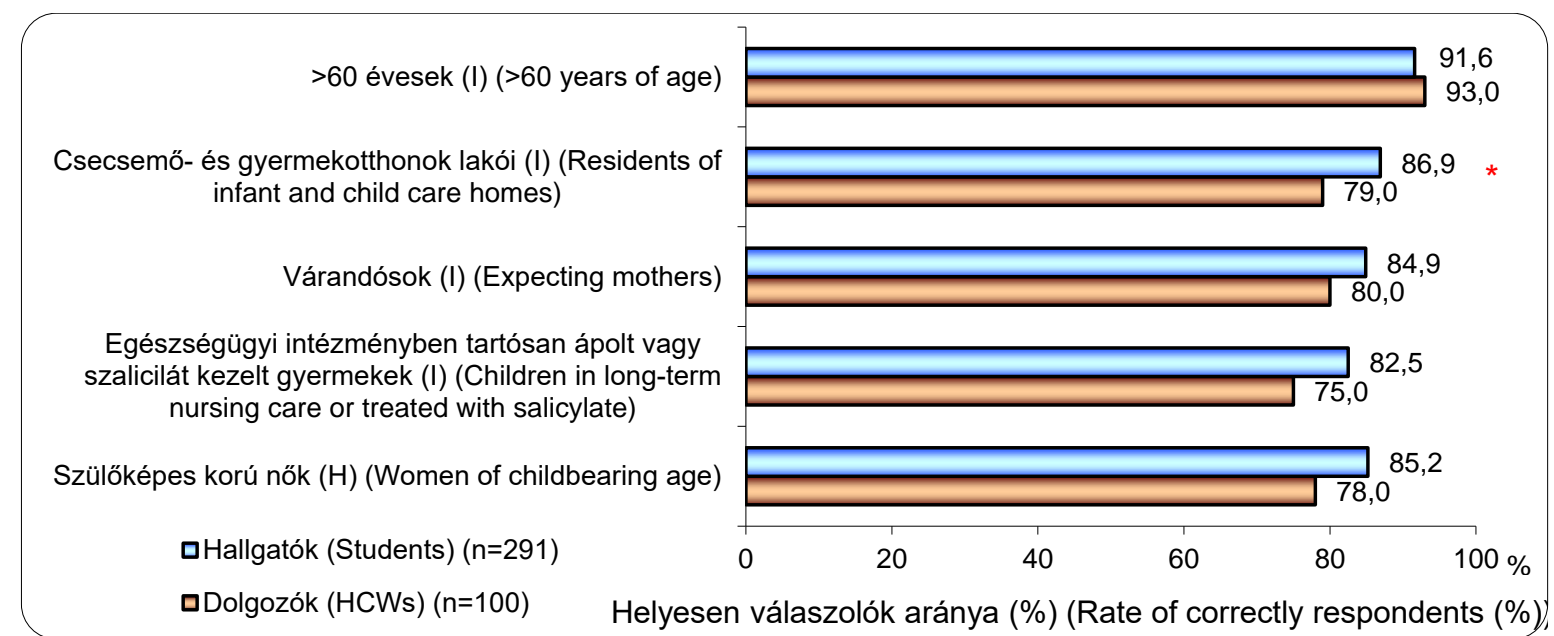

3. ábra Az influenza rizikócsoportokat helyesen megjelölők aránya (\%)

Jelmagyarázat: I: igaz válasz; H: hamis válasz

Figure 3 Percentage of people correctly identifying influenza risk groups

Legends: HCWs: health care workers; I: true answer; H: false answer

A betegekkel/ellátottakkal közvetlen kapcsolatba kerülés gyakorisága (sosem, ritkán, folyamatosan) a női hallgatók esetén a rizikócsoportba tartozás helyes tudásának mértékével (score=0-5, azaz 0-100\% tudásszinttel), míg a férfi hallgatóknál csupán a 60 éven felüliek veszélyeztetett csoportba tartozásának ismeretszintjével (score $=0-1)$ mutatott szignifikáns ( $\mathrm{p}=0,060$; illetve $\mathrm{p}=0,033)$ összefüggést.

A rizikócsoportba tartozás helyes tudásának pontszáma (score értéke) szignifikáns $(p=0,038)$ különbséget mutatott dolgozók és hallgatók esetében (4. ábra).

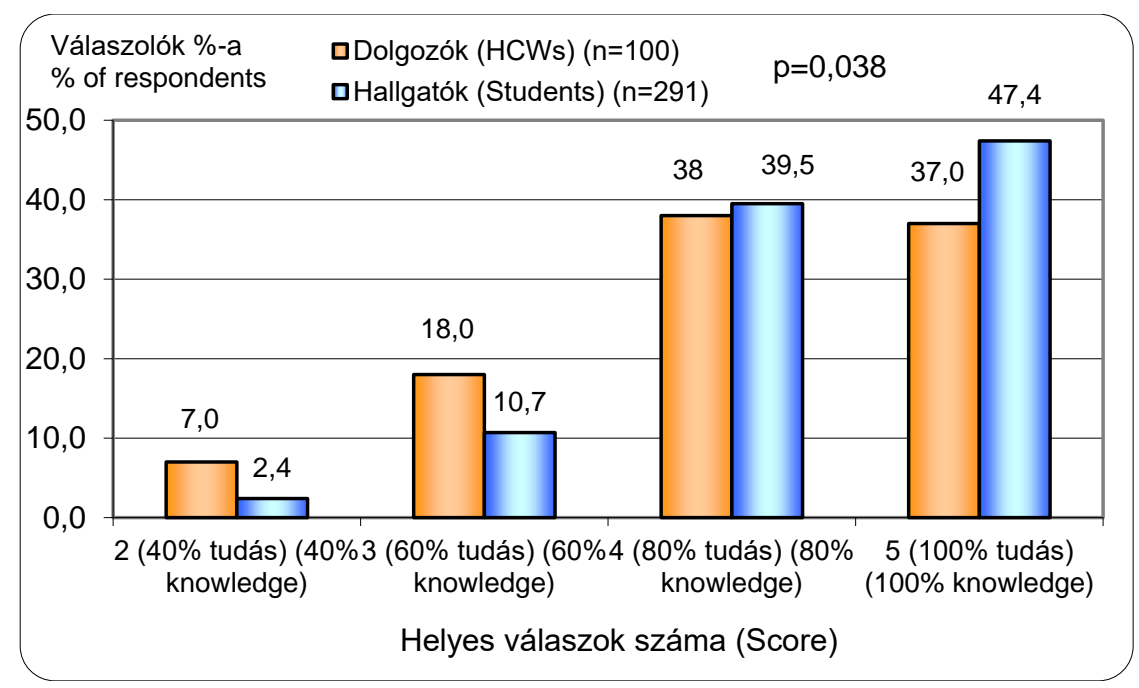

4. ábra A rizikócsoportba tartozás helyes tudásának pontszáma

Figure 4 Scores that measure the correct knowledge of belonging in the risk group 
A veszélyeztetett csoportba tartozás helyes ismeretének pontszáma (score $=0-5)$ a dolgozók esetében szignifikáns $(\mathrm{p}=0,023)$ összefüggést mutatott az aktív betegellátásban történő részvétel mértékével (sosem, ritkán, folyamatosan) (5. ábra), míg a hallgatóknál $(\mathrm{p}=0,001)$ a különböző SZTE Karokon tanulmányokat folytatással (6. ábra), azaz az eltérő szintü/mélységü és óraszámú ismereteket nyújtó képzési típusokkal.

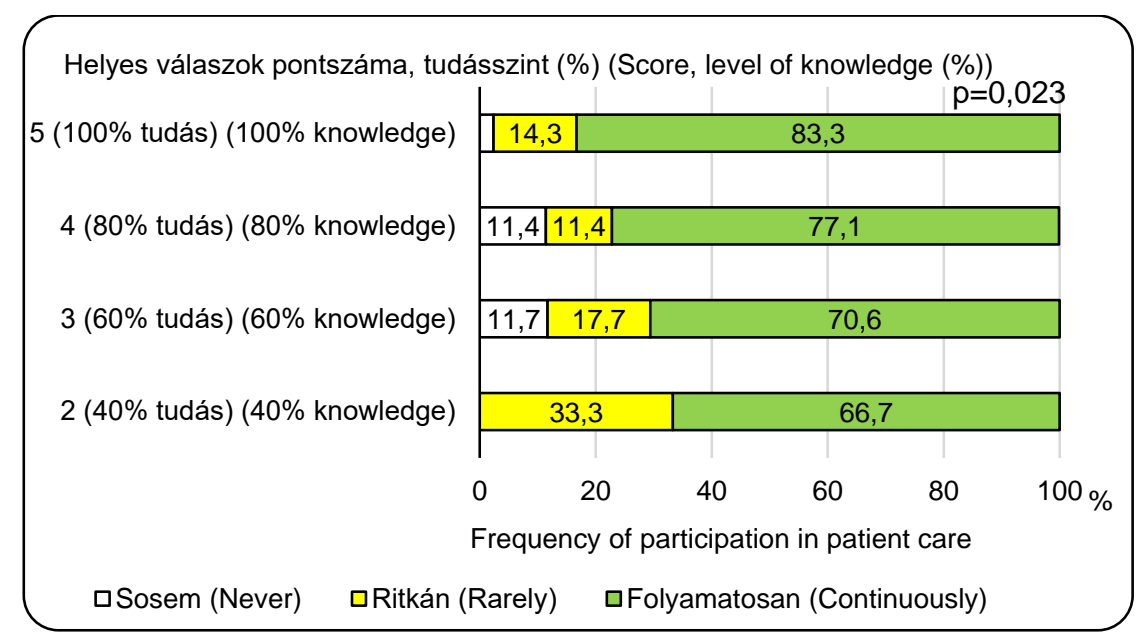

5. ábra A helyes „rizikó-pontszám” összefüggése a betegellátásban való részvétel intenzitásával a dolgozók $(\mathrm{n}=100)$ körében

Figure 5 Connection between the „risk-score” and the intensity of participation in the patient care, among the HCWs $(n=100)$

A fentiekben felsorolt (és 3. ábrán feltüntetett) rizikócsoportokat az orvostanhallgatók 60\%-a, míg az ETSZK hallgatók 33\%-a jelölte meg hibátlanul. Ennél a kérdésnél a legalacsonyabb helyes válaszok pontszáma a fogorvostan-, a gyógyszerész és orvostanhallgatók esetében 3, míg az ETSZK hallgatók körében 2 volt (6. ábra). 


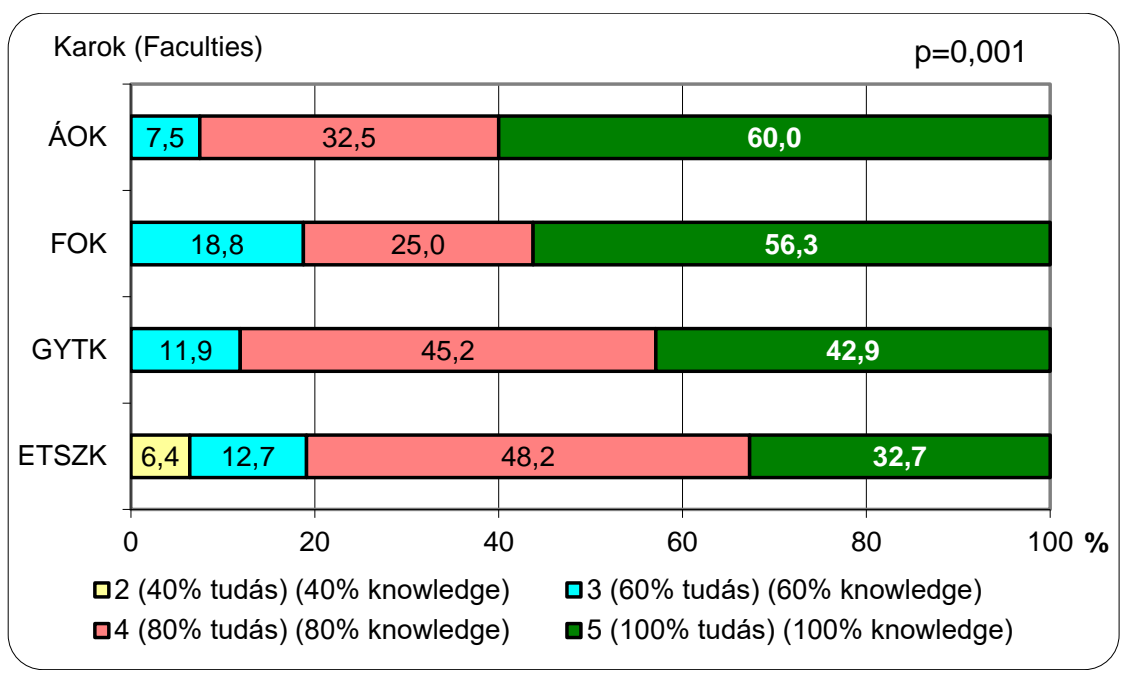

6. ábra A rizikócsoportok helyes ismeretszintjének (score) összefüggése az SZTE különböző karain tanulással

Figure 6 Connection between giving the correct score of the risk groups and studying at various Faculties of the University of Szeged

Legends: ÁOK: Faculty of Medicine; FOK: Faculty of Dentistry; GYTK: Faculty of Pharmacy; ETSZK: Faculty of Health Sciences and Social Studies

Az influenza kialakulását segítő (hajlamosító) tényezőket (túlzsúfoltság, szegénység, alultápláltság, a szervezet csökkent ellenállóképessége) helyesen jelölte meg a dolgozók 76\%-a és a hallgatók 86,6\%-a.

A kórkép egyik leggyakoribb súlyos, esetenként letális kimenetelü szövődményét, a tüdőgyulladást a dolgozók 83\%-a, míg a hallgatók 78\%-a jól tudta. Legkevésbé volt eredményes az influenza járványveszélyes szezonban gyakran egyidőben jelenlévő és kevéssé jól tudott (orrdugulással és tüsszögéssel járó) nátha és influenza tüneteinek (magas láz, fokozódó fejfájás, kiterjedt izomfájdalom, köhögés) felismerése, melyet csupán a hallgatók 40\%-a és a dolgozók 46\%-a különített el helyesen.

A megkérdezettek ( $\mathrm{n}=391)$ többsége $(83,5 \%$-a; 252 hallgató és 75 dolgozó) 80100\%-os (score=4-5) tudásszintet mutatva helyesen jelölte meg az influenza rizikócsoportba tartozókat, azon belül is legeredményesebben a 60 éven felüli korosztály kockázatnak kitettségét (3. ábra). Szintén magas arányban (365 fö, a válaszolók 96,1\%-a) tudták, hogy az influenza elsősorban cseppfertőzéssel terjed. Azonban azt a tényt, hogy a kórokozó szennyezett kézzel is átvihető, pl. nem megfelelő kézhigiénés tevékenység esetén az egészségügyi dolgozóról az ellátott (pl. 60 éven felüli, krónikus légzőszervi, /szívérrendszeri betegségben szenvedő stb.) személyekre, a válaszolók sokkal kisebb arányban 
(301 fö, az erre válaszolók 79,2\%-a) tudták (III. táblázat). Így kevésbé meglepő, hogy a felmérésben résztvevők 4,1\%-a (a női hallgatók 4,9\%-a, és dolgozók 2,7\%-a, továbbá a férfi hallgatók 1,2\%-a, míg a férfi dolgozók $8 \%$-a) esetén nem tudatosult saját maguk veszélyeztető csoportba tartozása. Az egészségügyi dolgozók influenza fertőzés terjedésében betöltött vektor szerepét a nők 95,7\%-a (286 fö), míg a férfiak 96,7\%-a (89 fö) ismerte fel megfelelően (II. táblázat).

A térítésmentes influenza oltásra jogosult, veszélyeztető csoportba tartozó személyeket (egészségügyi dolgozók, hosszú ápolási idejü ápolást/gondozást nyújtó szociális intézmények dolgozói) és a nem közéjük tartozókat (pedagógusok, kereskedelemben dolgozók) 100\%-ban helyesen felismerők (score=4) aránya magasabb volt a hallgatók körében (53 fö, 18,2\%; hallgató nők 17,9\%-a, hallgató férfiak 19,4\%-a), mint a dolgozókéban (13 fö, 13\%; dolgozó nők 13,3\%-a, dolgozó férfiak 12\%-a). A hosszú ápolási idejű intézmények dolgozóinak veszélyeztető csoportba való helyes besorolása a női és férfi hallgatók esetén szignifikáns $(\mathrm{p}=0,024 ; \mathrm{p}=0,004)$ összefüggésben állt az influenzával kapcsolatban feltett 9 igaz-hamis állítás helyes ismeretének pontszámával (score=0-9) (III. táblázat). A veszélyeztető csoportba tartozók helyes ismeretszintje (0100\%-os, azaz score=0-4 értéke) a hallgatók esetében a szignifikancia határán álló összefüggést mutatott $(\mathrm{p}=0,057)$ a betegekkel kapcsolatba kerülés gyakoriságával, míg a dolgozók körében szignifikáns $(\mathrm{p}=0,026)$ kapcsolatban állt a kórokozó szennyezett kézzel terjedési lehetőségének tudásával.

A dolgozó nők háromnegyed része (57 fö, 76\%), míg a dolgozó férfiak kétharmada (17 fö, 68\%) 3 helyes választ adott (75\% tudásszint) a négyböl, azonban közülük a nők 2,7\%-ának ( 2 fö) tudásszintje $0 \%$ volt ezen a területen. A férfi dolgozók ötöde ( 5 fö) legalább 2 veszélyeztető csoportot jelölt meg jól. A női hallgatók 66\%-a, míg a férfi hallgatók $57 \%$-a adott 3 jó választ (75\%-os tudásszint) és a hallgatók közel ötöde $100 \%$ ismeretszintet (score=4) ért el. A hallgatók közül ebben a kérdésben legkevesebb (score=1) pontot 10 női hallgató szerzett. 
II. táblázat Térítésmentes oltásra jogosult, veszélyeztető személyek ismerete Table II Knowledge of possible professional transmitters who are eligible for free vaccination

\begin{tabular}{|c|c|c|c|c|c|c|}
\hline \multirow{3}{*}{$\begin{array}{l}\text { A kockázati csoportokat } \\
\text { veszélyeztető személyek } \\
\text { Persons endangering the risk } \\
\text { groups }\end{array}$} & \multicolumn{6}{|c|}{$\begin{array}{l}\text { Helyesen válaszolók aránya (\%) és száma (fö) } \\
\text { Proportion (\%) and number of people answering correctly }\end{array}$} \\
\hline & \multicolumn{2}{|c|}{$\begin{array}{l}\text { Dolgozók (HCWs) } \\
\quad(\mathrm{n}=100)\end{array}$} & \multicolumn{4}{|c|}{$\begin{array}{l}\text { Hallgatók (Students) } \\
(\mathrm{n}=291)\end{array}$} \\
\hline & $\begin{array}{c}\text { Nők } \\
\text { (Female) } \\
(\mathrm{n}=75)\end{array}$ & $\begin{array}{l}\text { Férfiak } \\
\text { (Male) } \\
(\mathrm{n}=25)\end{array}$ & $\begin{array}{l}\text { Összesen } \\
\text { Together } \\
(n=100)\end{array}$ & $\begin{array}{c}\text { Nők } \\
\text { (Female) } \\
(n=224)\end{array}$ & $\begin{array}{l}\text { Férfiak } \\
\text { (Male) } \\
(67)\end{array}$ & $\begin{array}{l}\text { Összesen } \\
\text { Together } \\
(n=291)\end{array}$ \\
\hline $\begin{array}{l}\text { Egészségügyi dolgozók (I) } \\
\text { Health care workers (HCWs) }\end{array}$ & $\begin{array}{l}97,3 \% \\
(73)\end{array}$ & $\begin{array}{l}92,0 \% \\
(23)\end{array}$ & $\begin{array}{l}96 \% \\
(96)\end{array}$ & $\begin{array}{l}95,1 \% \\
(213)\end{array}$ & $\begin{array}{l}98,5 \% \\
(66)\end{array}$ & $\begin{array}{l}95,9 \% \\
(279)\end{array}$ \\
\hline $\begin{array}{l}\text { Hosszú idejü ápolást/gondozást } \\
\text { nyújtó szociális intézmények } \\
\text { dolgozói (I) } \\
\text { Employees of institutions } \\
\text { providing long-term care }\end{array}$ & $\begin{array}{l}89,3 \% \\
(67)\end{array}$ & $\begin{array}{l}88,0 \% \\
(22)\end{array}$ & $\begin{array}{l}89 \% \\
(89)\end{array}$ & $\begin{array}{l}81,7 \% \\
(183)\end{array}$ & $\begin{array}{l}89,6 \% \\
(60)\end{array}$ & $\begin{array}{l}83,5 \% \\
(243)\end{array}$ \\
\hline $\begin{array}{l}\text { Pedagógusok }(\mathrm{H}) \\
\text { Teachers }\end{array}$ & $\begin{array}{c}69,3 \% \\
(52)\end{array}$ & $\begin{array}{c}68,0 \% \\
(17)\end{array}$ & $\begin{array}{l}69 \% \\
(69)\end{array}$ & $\begin{array}{c}68,8 \% \\
(154)\end{array}$ & $\begin{array}{c}58,2 \% \\
(39)\end{array}$ & $\begin{array}{c}66,3 \% \\
(193)\end{array}$ \\
\hline $\begin{array}{l}\text { Kereskedelemben dolgozók (H) } \\
\text { Retail workers }\end{array}$ & $\begin{array}{c}40,0 \% \\
(30)\end{array}$ & $\begin{array}{l}44,0 \% \\
(11)\end{array}$ & $\begin{array}{l}41 \% \\
(41)\end{array}$ & $\begin{array}{l}51,8 \% \\
(116)\end{array}$ & $\begin{array}{l}49,3 \% \\
(33)\end{array}$ & $\begin{array}{c}43,6 \% \\
(127)\end{array}$ \\
\hline $\begin{array}{l}\text { Helyes válaszok pontszáma } \\
\text { (átlag } \pm \text { SD), } \\
\text { Score }(\text { mean } \pm \text { SD) }\end{array}$ & $\begin{array}{l}\mathbf{2 , 9 6} \\
\pm 0,706 \\
\min : 0 \\
\max : 4\end{array}$ & $\begin{array}{l}\mathbf{2 , 9 2} \\
\pm 0,572 \\
\min : 2 \\
\max : 4\end{array}$ & $\begin{array}{l}2,94 \\
\pm 0,677 \\
\min : 0 \\
\max : 4\end{array}$ & $\begin{array}{l}\mathbf{2 , 9 7} \\
\pm 0,689 \\
\min : 1 \\
\max : 4\end{array}$ & $\begin{array}{c}\mathbf{2 , 9 6} \\
\pm 0,661 \\
\min : 2 \\
\max : 4\end{array}$ & $\begin{array}{l}2,97 \\
\pm 0,682 \\
\min : 1 \\
\max : 4\end{array}$ \\
\hline
\end{tabular}

Jelmagyarázat: I: igaz állítás; H: hamis állítás; SD: szórás;

Legends: I: true statement; H: false statement; SD: standard deviation; HCWs: health care workers; score: number of correct answers; min: the lowest score achieved; max: the highest score achieved

Az influenza betegséggel kapcsolatos 9 állítást tartalmazó kérdésre 378 fö válaszolt, akiknek több mint a fele (196 fö; 54 dolgozó - a nök 56\%-a, a férfiak 61\%-a, valamint 142 hallgató: a nök 53\%-a, férfiak 45\%-a) helyesen jelölte meg a 6 igazat és a 3 hamisat (score $=9$ pont; 100\%-os tudásszint). A hibátlan válaszok pontszámának átlaga a

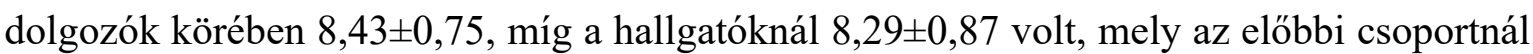
94\%-os, míg az utóbbinál 92\%-os tudásszintet jelent. A betegséggel kapcsolatos helyes válaszok (tudás) pontszáma („,betegség score-pont=0-9”) nők esetében szignifikáns összefüggést mutatott az iskolai végzettséggel (dolgozók: $p=0,002$; hallgatók: $p=0,002$ ), továbbá a női hallgatóknál a különböző SZTE karokon tanulmányokat folytatással $(\mathrm{p}<0,001)$ és az influenza tünetek tudásának pontjával $(\mathrm{p}=0,002)$, míg a férfi dolgozóknál a felmérést megelőző utolsó 3 évi (időnként, rendszeresen) oltás gyakorisággal $(p=0,025)$. A hallgatók esetén a nők adták a legkevesebb helyes választ (5 pont) (3 fö), míg a férfiaktól legalább 6 ( 1 fö) helyes válasz érkezett. A dolgozók legalacsonyabb pontszáma nők esetén 6 (2 fö), férfiaknál 8 (9 fö) volt az elérhető kilencből. 
A helyes válaszadási rangsor szerint a dolgozók leginkább a betegség légúti terjedési módját, a kórokozó rendszertani besorolását, az egészségügyi dolgozók influenza fertőzésnek kitettségét és a betegség átvészeltségét követő tartós immunitás hiányát tudták jól. A legtöbb hallgató ismerte, hogy az aktív betegellátásban tevékenykedők influenza szempontjából a veszélyeztetett és a veszélyeztető csoportba is tartoznak. Legkevésbé volt ismert a fertőzés szennyezett kézzel terjedésének lehetősége. Azt, hogy a betegség súlyos, akár halálos kimenetelű szövődménnyel is járhat, minden 20. dolgozó, illetve 10. hallgató nem tudta. Ebben a kérdésben tudásszintjük szignifikáns $(p=0,046)$ különbséget mutatott.

A válaszoló dolgozók 79,6\%-a és a hallgatók közel 82\%-a értett egyet azzal, hogy a védőoltás a leghatékonyabb módszer az influenza megelőzésére, mely szignifikáns összefüggésben állt a dolgozó és hallgató nők valaha influenza oltottságával ( $p=0,020 ; p=0,012)$, valamint a női hallgatók felmérést megelőző utolsó 3 évi (időnként, rendszeresen) oltás gyakoriságával ( $\mathrm{p}=0,031)$. A 380 fö közül az influenzával kapcsolatos 9 állításra adott helyes válaszok rangsora alapján csupán az utolsó (7.) helyen és legkevesebben (tízböl nyolcan) fogadták el helyesnek a védőoltás prevencióban betöltött leghatékonyabb szerepét (III. táblázat).

III. táblázat Az influenzával kapcsolatos ismeretek felmérése

Table III Assessing the knowledge about flu

\begin{tabular}{|c|c|c|c|c|c|c|c|}
\hline \multirow{3}{*}{$\begin{array}{l}\text { Állítások } \\
\text { Statements }\end{array}$} & \multicolumn{6}{|c|}{ Helyes válaszadások, Correct answers } & \multirow{3}{*}{$\begin{array}{l}\mathrm{P} \text { érték } \\
\mathrm{P} \text { value }\end{array}$} \\
\hline & \multicolumn{4}{|c|}{$\begin{array}{l}\text { Rangsora } \\
\text { Ranking }\end{array}$} & \multicolumn{2}{|c|}{$\begin{array}{l}\text { Aránya (\%) és száma (fó) } \\
\text { Proportion \%, number }\end{array}$} & \\
\hline & $\mathrm{D}$ & $\mathrm{H}$ & $\Sigma$ & $\begin{array}{c}\text { D } \\
\text { HCWs } \\
(n=98)\end{array}$ & $\begin{array}{c}\mathrm{H} \\
\text { Students } \\
(\mathrm{n}=282)\end{array}$ & $\begin{array}{c}\Sigma \\
(n=380)\end{array}$ & \\
\hline $\begin{array}{l}\text { A megbetegedést } \\
\text { vírus okozza. (I) } \\
\text { The disease is } \\
\text { caused by a virus. }\end{array}$ & 2. & 4. & 3. & $98,0 \%(96)$ & $95,8 \%(270)$ & $96,3 \%(366)$ & $\mathrm{p}=0,367$ \\
\hline $\begin{array}{l}\text { Elsősorban } \\
\text { cseppfertőzéssel } \\
\text { terjed. (I) } \\
\text { It spreads mainly by } \\
\text { airborne droplets. }\end{array}$ & 1. & 5. & 4. & $99,0 \%(97)$ & $95,0 \%(268)$ & $96,1 \%(365)$ & $p=0,052$ \\
\hline $\begin{array}{l}\text { Szennyezett kézzel } \\
\text { is terjedhet. (I) } \\
\text { It may spread with } \\
\text { soiled hands. }\end{array}$ & 5. & 9. & 8. & $82,7 \%(81)$ & $78,0 \%(220)$ & $79,2 \%(301)$ & $\mathrm{p}=0,294$ \\
\hline $\begin{array}{l}\text { Terjedhet a betegröl } \\
\text { az egészségügyi } \\
\text { dolgozóra. (I) } \\
\text { It can spread from } \\
\text { patient to health } \\
\text { care worker. }\end{array}$ & 2. & 1. & & $98,0 \%(96)$ & $99,3 \%(280)$ & $99,0 \%(376)$ & $\mathrm{p}=0,277$ \\
\hline
\end{tabular}


Az egészségügyi

dolgozóról nem

terjedhet a betegre.

(H)

3. 2. 2. $96,0 \%(94) \quad 97,9 \%(276) \quad \mathbf{9 7 , 4 \%}(370) \quad \mathrm{p}=0,437$

It cannot spread

from health care

worker to patient.

A tünetmentes

influenzás személy

nem fertőz meg

másokat. $(\mathrm{H})$

The asymptomatic

4. 3. 3. $93,9 \%(92) \quad 97,2 \%(274) \quad \mathbf{9 6 , 3 \%}(366) \quad \mathrm{p}=0,201$

influenza carrier

does not infect

others.

Súlyos/halálos

kimenetelü is lehet,

különösen $a>60$

évesek esetében. (I)

It can be serious /

$91,1 \%(257)$

$92,6 \%(352)$

$p=0,046$

fatal, especially in

people $>60$ years of

age.

Átvészeltsége

$100 \%$-os

védettséget ad. $(\mathrm{H})$

2. 6. 5. $98,0 \%(96)$

$92,9 \%(262)$

$94,2 \%(358)$

$p=0,075$

Infection induces

$100 \%$ immunity.

Leghatékonyabban

az influenza elleni

vakcinával előzhető

meg. (I)

Its most effective

$81,3 \%$ (309)

$\mathrm{p}=0,777$

prevention is by a

flu vaccine.

Helyes válaszok

pontszáma (átlag $\pm \mathrm{SD}$ )

Score $($ mean $\pm \mathrm{SD})$

$\begin{array}{ccc}\mathbf{8 , 4 3} & \mathbf{8 , 2 9} & \mathbf{8 , 3 3} \\ \pm 0,75 & \pm 0,87 & \pm 0,84 \\ \min : 6 ; & \min : 5 ; & \min : 5 ; \\ \max : 9 & \max : 9 & \max : 9\end{array}$

$\mathrm{p}=0,757$

$\max : 9$

Jelmagyarázat: D: dolgozók; H: hallgatók; $\Sigma$ : összes; I: igaz állítás, H: hamis állítás, SD: szórás, min: minimum helyes válaszok száma, max: maximum helyes válaszok száma

Legends: D: healthcare workers; H: students; $\Sigma$ : together; HCWs: health care workers; I: true statement, H: false statement, SD: standard deviation, score: number of correct answers; min: the lowest score achieved; max: the highest score achieved

\section{A védőoltással kapcsolatos ismeretek}

A térítésmentes szezonális influenza vakcinával és oltási lehetőséggel kapcsolatban magát kellően informáltnak valló dolgozók aránya (76,5\%) kétszerese volt a hallgatókénak (39,6\%), mégis arányaiban másfélszer több hallgató $(61,4 \%)$ tudta, hogy a vakcina nem okoz influenzát. A megkérdezettek kevesebb, mint fele (44,4\%) tisztában volt azzal, hogy az oltóanyag nem nyújt 100\%-os védelmet. Csupán a dolgozók 20\%-a és a hallgatók 
17,8\%-a értesült a hazai egészségügyi dolgozók 2010 óta tartó folyamatosan csökkenő átoltottságáról. A válaszadók kétharmada (dolgozók 64\%-a, a hallgatók 62\%-a) egyetértett a vakcina biztonságosságával, továbbá $66 \%$, illetve $68 \%$ az aktív betegellátásban résztvevő dolgozók és hallgatók magas (legalább 70\%-os) átoltottságával, azonban körükben csupán 62-63\% tartotta fontosnak önmaga oltottságát. A 2017/2018. évi influenza járványveszélyes szezonban a legtöbb hallgató nem tudott a térítésmentes központi oltóanyaggal történő oltásra jogosultságáról.

\section{Oltásajánlás és oltottsági státusz}

A megkérdezettek számára a térítésmentes oltás felvételének lehetőségét leggyakrabban az (alapellátásban dolgozó) orvosok (72\%) ajánlották, azonban a hallgatók erről való tájékozatlansága alapján feltehetően nem kellően motiválóan. Az információk a dolgozók 4/5-éhez, míg a hallgatók alig több mint feléhez jutottak el. Aggodalomra ad okot, hogy a média (36\%), a családtagok (29\%) és az ismerősök (21\%) immunizációs ajánlása megelőzte a gyógyszerészekét (19\%) és az egészségügyi szakdolgozókét (nővér, asszisztens: $8,5 \%$ ).

A dolgozók közel 60\%-a vallotta magát életében valaha oltottnak, ezen belül kétharmadukat időnként vagy rendszeresen a kutatást megelőző utolsó 3 évi influenza szezonban és egyharmadukat csupán ennél régebben immunizálták. A 2017/2018. évi szezonban a munkavállalók 36,3\%-a élt a vakcina nyújtotta védelemmel. Átoltottságuk gyakorisága szignifikánsan magasabb volt a hallgatók 36,6\%-os valaha ( $\mathrm{p}<0,001)$, a 49,5\%-os 2014/2015 - 2016/2017. közötti $(p=0,036)$ és a 13,2\%-os 2017/2018. évi szezonban történő $(\mathrm{p}<0,001)$ aktív immunizálásánál. A valaha oltottságuk aránya megközelítöleg másfélszerese, míg a vizsgált legutolsó influenza szezonban vallotté közel háromszorosa volt a hallgatókénak. A 2014/2015. évi - 2016/2017. évi szezonokban a 4 SZTE karon tanuló hallgatók oltás gyakorisága szignifikáns $(\mathrm{p}<0,001)$ eltérést mutatott egymástól (IV. táblázat). 
IV. táblázat Influenza átoltottsági arányok (\%)

Table IV Influenza vaccination coverage rates

\begin{tabular}{|c|c|c|c|c|c|}
\hline \multirow{3}{*}{\multicolumn{2}{|c|}{$\begin{array}{l}\text { A vizsgálatban résztvevők } \\
\text { Participants in the questionnaire survey }\end{array}$}} & \multirow{3}{*}{$\begin{array}{l}\text { Életében } \\
\text { valaha } \\
\text { Ever in } \\
\text { lifetime }\end{array}$} & \multicolumn{2}{|c|}{$\begin{array}{l}\text { Influenza oltott }(\%, \text { fó }) \\
\text { Flu vaccinated }\end{array}$} & \multirow{3}{*}{$\begin{array}{l}2017 / 2018 \\
\quad \text { évi } \\
\text { szezonban } \\
\text { In season } \\
\text { 2017-2018 }\end{array}$} \\
\hline & & & \multicolumn{2}{|c|}{$\begin{array}{l}\text { 2014/2015. évi }-2016 / 2017 \text {. évi } \\
\text { Szezonokban } \\
\text { In seasons 2014-2017 }\end{array}$} & \\
\hline & & & $\begin{array}{l}\text { Egyszer sem } \\
\text { Never }\end{array}$ & $\begin{array}{l}\text { Igen } \\
\text { Yes }\end{array}$ & \\
\hline \multirow{6}{*}{$\begin{array}{l}\text { SZTE } \\
\text { karok } \\
\text { hallgatói } \\
\text { Students } \\
\text { of } \\
\text { University } \\
\text { of Szeged }\end{array}$} & ÁOK & $39,2 \%$ & $31,9 \%$ & $68,1 \%$ & $16,7 \%$ \\
\hline & GYTK & $40,5 \%$ & $47,1 \%$ & $52,9 \%$ & $19,4 \%$ \\
\hline & FOK & $25,0 \%$ & $100,0 \%$ & $0,0 \%$ & $0,0 \%$ \\
\hline & ETSZK & $33,9 \%$ & $70,3 \%$ & $29,7 \%$ & $6,7 \%$ \\
\hline & $\begin{array}{l}\text { Összesen; } \\
\text { Together }\end{array}$ & $36,6 \%$ & $50,5 \%$ & $49,5 \%$ & $13,2 \%$ \\
\hline & $\mathrm{P}$ érték; $\mathrm{P}$ value & $\mathrm{p}=0,599$ & \multicolumn{2}{|c|}{$p=0,001$} & $\mathrm{p}=0,093$ \\
\hline \multicolumn{2}{|c|}{$\begin{array}{l}\text { Dolgozók; } \\
\text { Health care workers }\end{array}$} & $59,0 \%$ & $33,3 \%$ & $66,7 \%$ & $36,3 \%$ \\
\hline \multicolumn{2}{|c|}{ Együtt; Altogether } & $43,0 \%$ & $44,4 \%$ & $55,6 \%$ & $19,4 \%$ \\
\hline \multicolumn{2}{|c|}{ P érték; P value } & $p<0,001$ & \multicolumn{2}{|c|}{$p=0,036$} & $p<0,001$ \\
\hline
\end{tabular}

Legends: ÁOK: Faculty of Medicine; FOK: Faculty of Dentistry; GYTK: Faculty of Pharmacy; ETSZK: Faculty of Health Sciences and Social Studies

A valaha oltottak a térítésmentes oltóanyagot preferálták (dolgozók 86\%-a és a hallgatók 71\%-a) a gyógyszertárból beszerezhetővel szemben.

A betegellátásban résztvevő valaha vakcinált dolgozók aránya $61,5 \%$, míg a hallgatóké csupán ennek a fele (30,6\%) volt. Kiemelendö, hogy az aktív betegellátásban tevékenykedő korábban még soha nem oltott dolgozók több mint a fele (55\%-a) és a hallgatók 1/3-a (31\%-a) biztos volt abban, hogy ezután sem veszi fel az influenza megelőzésére szolgáló védőoltást.

\section{Oltási hajlandóság}

Az influenza elleni védőoltásban még soha nem részesültek (224 fö; 41 dolgozó és 183 hallgató) oltás elutasításának leggyakoribb oka volt, hogy 41,5\%-uk (93 fö; dolgozók 39\%a, illetve hallgatók 42,1\%-a) az ismeretei alapján nem tartotta magát veszélyeztetettnek, továbbá a dolgozók egyötöde (9 fö) és a hallgatók egynegyede (43 fó) úgy gondolta, hogy más módszerekkel is ugyanolyan hatékonyan megelőzhető a megbetegedés és szövődménye, mint a védőoltással. Minden 4. hallgató és 7. dolgozó vallotta azt, hogy 
meglévő információi alapján nem tartja fontosnak az oltás felvételét és ennek kétharmadát (35 fö) tartotta vissza a félelem a vakcinációval járó kellemetlenségektől (pl. az oltást követő nemkívánatos eseménytől, az injekciótól). Az oltási hajlandóságot kedvezőtlenül befolyásoló tényezők közül a félelemérzet és a vakcináció kevésbé fontosnak tartása közötti különbség a dolgozók és a hallgatók esetén a szignifikancia határához közel mozgott $(\mathrm{p}=0,087 ; \mathrm{p}=0,090)$. A korábban még soha nem oltott dolgozók egészségért érzett felelössége (úgy gondolják, hogy keveset, sokat, nagyon sokat tehetnek önmaguk egészségéért) szignifikáns $(\mathrm{p}=0,004)$ összefüggést mutatott az oltáselutasítás félelmi komponensével. Egy női dolgozó és 8 hallgató (1 férfi és 7 nő) oltásellenesnek vallotta magát, 3 dolgozó és 25 hallgató más védőoltást sem szokott felvenni, 5 női hallgató pedig még nem hallott az influenza védőoltással történő megelőzési lehetőségéről. Az egyéb oltás elmaradási okok között a hallgatók a térítésmentes oltás felvételéröl való tájékoztatás hiányát, halogatást, súlyosnak ítélt saját oltást követő nemkívánatos esemény (OKNE) tapasztalatát, egy esetben vallási okot, illetve oltóanyag allergiát és gyártói érdekeltséget, valamint rövid ideig tartó és nem 100\%-os immunvédelmet soroltak fel. Ezzel szemben a dolgozók inkább időhiánnyal, vagy helyette más, munkakörhöz kötött kötelező védőoltás felvételének fontosabbnak tartásával, továbbá az influenza vakcina nem elég magasnak vélt hatékonyságával és az ismeretségi körben szerzett negatív tapasztalatokkal indokolták influenza oltatlanságukat (7. ábra).

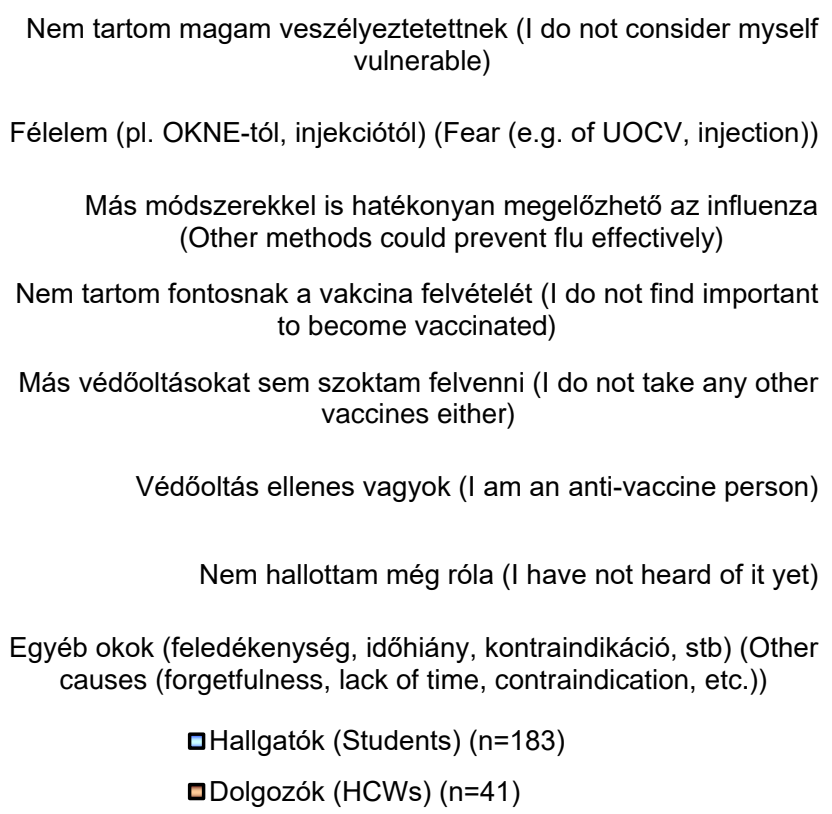

7. ábra Az oltatlanok oltás elutasításának okai

Figure 7 Reasons for refusal among non-vaccinees 
Az időnként vakcinázottak (120 fö; 35 dolgozó és 85 hallgató) számára saját és/vagy családtagjaik egészségének védelme volt motiváló, azonban a korábban előforduló súlyos OKNE élmény számukra is visszatartó erőnek bizonyult.

A rendszeresen immunizáltak (47 fö; 24 dolgozó és 23 hallgató) évenkénti oltásfelvételét elsősorban (72,3\%, 15 dolgozó és 19 hallgató esetében) az influenza vakcina nyújtotta immunvédelembe vetett bizalom motiválta. Ugyanilyen fontos szerepet töltött be a dolgozók (15 fö, 62,5\%) vakcinákba vetett általános bizalma és a hallgatók (19 fó, 82,6\%) influenza oltóanyaggal kapcsolatos tudományos ismeretek birtokában meghozott döntése. Az oltóanyaggal kapcsolatos tudás a dolgozók rendszeres oltásfelvételi döntésében a bizalom után a 2. helyen állt, melyet sorrendben (a hallgatókhoz hasonlóan) a bizonyosság az oltás hatásosságáról érve követett. Az oltóanyag térítésmentes elérhetősége nem szerepelt az évenkénti oltásgyakoriság első három helyen álló motiváló tényezői között. Három egészségügyi dolgozó (13\%) az ellátottak tudatos védelmét is szem előtt tartva élt a rendszeres oltási lehetőséggel és ugyanennyien erősítették immunrendszerüket külső (pl. munkáltatói) presszióra. Megszokott prevenciós lehetőségként vette igénybe a rendszeresen oltott dolgozók és hallgatók 4-4\%-a az oltás évenkénti megismétlését. Egyéb ösztönző tényezőként a hallgatók a felelősségtudatot és az oltáselmaradást követő saját influenza tapasztalatot, míg a dolgozók saját és környezetük egészségvédelmének szem elött tartását említették meg (8. ábra).

Bizalom az influenza vakcina immunvédelmében (Trust in the immunity provided by the flu vaccine)

Általában bízom a vakcinák nyújtotta védelemben (In general, I trust the protection afforded by vaccines)

Tudományos ismeretek az influenza vakcináról (Scientific knowledge about the influenza vaccine)

Bizonyosság az oltóanyag hatásosságáról és biztonságosságáró (Certainty about the efficacy and safety of vaccines)

Az oltás ingyenessége (Free vaccination)

Megszokás (Routine)

Külső (pl. munkáltatói) presszió (External pressure (e.g. by the employer))

Egyéb okok (pl. saját/ellátottak egészségének védelme, stb) (Other reasons (eg protecting the health of one's own / those in care, etc.))

口Hallgatók (Students) $(n=23)$

口Dolgozók(HCWs) $(\mathrm{n}=24)$

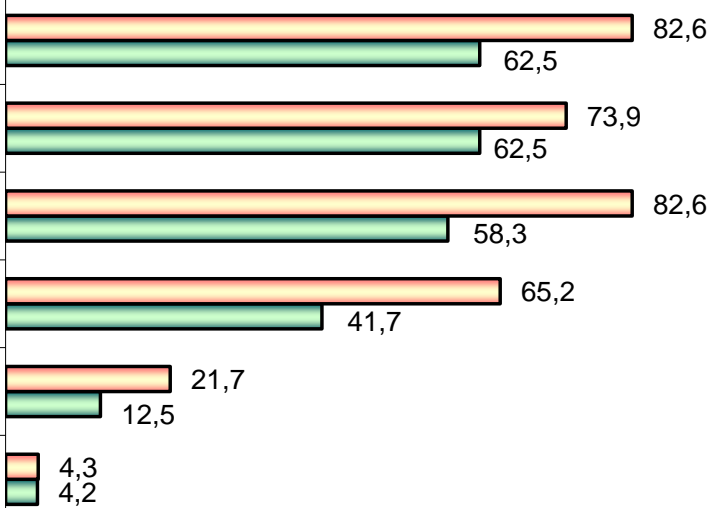

13,0

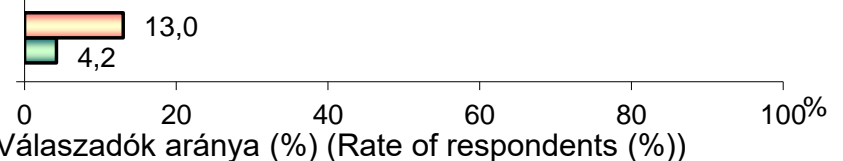

8. ábra A rendszeresen oltottak oltásfelvételének motivációja

Figure 8 The motivation of the vaccine uptake of regularly vaccinated persons 


\section{Az oltási attitüdöt befolyásoló tényezők}

A vizsgálatban résztvevő 391 fö közül 167 fő (42,7\%; 59 dolgozó - 42 nő, 17 férfi; és 108 hallgató - 84 nö, 24 férfi) részesült már életében valamikor influenza védőoltásban. A további elemeket magába foglaló befolyásolható fő tényezők (pl. félelem, oltóorvos, oltóhely, oltóanyag, konkrét rizikószituáció stb.) közül valamennyiük oltásfelvételi döntésében az információ/informáltság bizonyult a legfontosabbnak. Hat komponensének informáltság az influenzáról, az influenza oltóanyagról, az oltási lehetőségről, az információ elegendő mennyisége és minősége és a forrás hitelessége - többsége az 1-5 fontossági válaszskálán a legmagasabb pontértékeket kapta mind a dolgozók (3,6-4,0), mind a hallgatók $(3,9-4,4)$ körében. Annak ellenére, hogy a vakcinációs attitüd alakításban az egyik legfontosabbnak bizonyuló faktor fontossága nem mutatott szignifikáns eltérést a dolgozók $(3,82 \pm 0,67)$ és a hallgatók $(4,02 \pm 0,53)$ között, a hallgatók annak valamennyi elemét (pl. az elegendő tudást és a naprakész ismereteket) lényegesebbnek ítélték meg, mint az egészségügyi dolgozók (9. ábra).

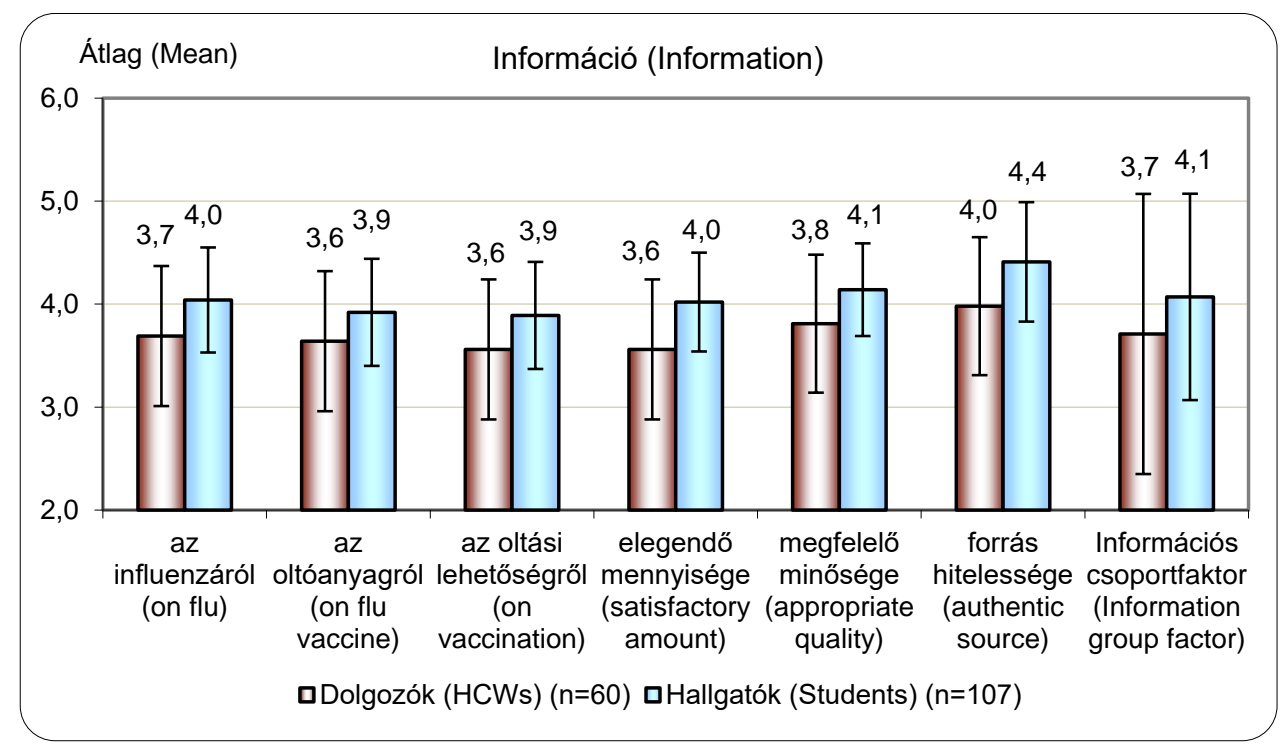

9. ábra $\mathrm{Az}$ 1-5 skálán fontosnak vélt informáltsági tényezők a valaha oltottak körében

Figure 9 On the scale of 1-5, awareness factors considered important among those who have ever been vaccinated

A dolgozók, az információ/informáltság mellett, a saját és családjukban lezajlott influenza

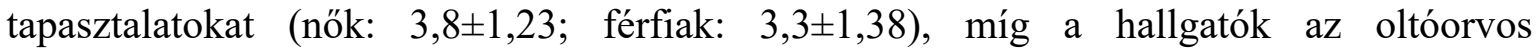




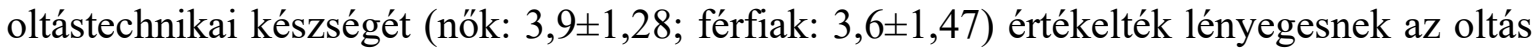
felvételi döntésük meghozatalában.

\section{Összefoglalás, következtetések}

Nemzetközi statisztikai adatok szerint az egészségügyi dolgozók influenza átoltottsági aránya a világ, köztük Európa különböző országaiban igen eltérő képet mutat, mely egyes EU tagállamok esetében a 2020-ig megvalósítandó 70\%-os WHO és EU/EEA célértékek alatti. Hazánkban az oltóanyag rizikócsoportok számára térítésmentes elérhetősége ellenére a 2010 körüli 50-60\%-os influenza oltottsági ráta folyamatosan csökkenve 2015-re elérte a 30\%-ot, majd kismértékü ingadozást követően a 2017/2018. évi szezonban átlépte azt (31,2\%) (9, 13, 16).

Fontos tény, hogy az oltóanyag beadását követő, 2 héten belül kialakuló (40-80\%os) és 24 hétig stabilan fennálló immunológiai védettség nem csak az oltott személyt, hanem annak otthoni és munkahelyi szoros kontaktjait (környezetét) is védi, csökkentve ezzel a fertőzés terjesztésének lehetőségét és a társadalomra nehezedő betegségteher mértékét. Az oltás - különösen a rizikócsoporthoz tartozóknál - komoly előnyökkel jár, így 70-90\%-kal csökkenti az influenza megbetegedés kialakulását, 21-27\%-kal csökkenti a $\geq 65$ éveseknél a hospitalizációt igénylő súlyos szövődmények kialakulását, 12-48\%-kal mérsékeli a halálos kimenetelű esetek számát (7); emellett a vakcinációnak nincs kontraindikációja.

Az egészségügyi ellátásban dolgozók oltottsági rátájának növelése bizonyítottan csökkenti a különösen magas rizikójú, időskorú ellátottak körében az influenza szövődmények súlyosságát és gyakoriságát, valamint mortalitási arányát (17).

Immunizálás hiányában azonban az oltatlan egészségügyi dolgozók/hallgatók veszélyeztetve a betegellátás biztonságát - forrásai (rezervoárjai) és közvetítői (vektorai) lehetnek pl. a nosocomialis influenza megbetegedéseknek és járványoknak.

Hazánkban a fokozottan veszélyeztetett kockázati csoportok számára rendelkezésre bocsátott (szezononként 1,3 millió adag) térítésmentes inaktivált influenza oltóanyag felhasználása csupán 50-60\% körüli (13). Az influenza védőoltásokkal kapcsolatos egyik legfontosabb feladat a lehető legtöbb térítésmentes oltásra jogosult számára beadni azt. Ehhez elengedhetetlen a korábbi évtizedben (populációs szinten is) tapasztalható csökkenő 
oltóanyag felhasználási trend megállítása, továbbá az oltási kedv, hajlandóság és az átoltottság fokozása, mely az utóbbi 3 szezonban 29-31\% körüli volt.

Ismert, hogy az influenza vakcináció fontosságának megértése és elfogadása (az egészségműveltség és részét képező oltási tudatosság) hazánkban szuboptimális szintű, továbbá igen gyakori az oltással kapcsolatos félreértés, félreinformáltság (18).

Kutatási eredményeink alapján megállapítható, hogy az egészségügyi ellátásban tevékenykedő dolgozók és hallgatók oltási magatartását alapvetően meghatározza az információ/informáltság az influenza betegségről, az oltóanyagról, az oltási lehetőségekröl, melyhez elengedhetetlenül fontosnak vélik a hiteles forrásból származó megfelelő minőségű és elegendő mennyiségü ismereteket. Ezért lényeges szerepe van a célcsoportspecifikus (hallgató, dolgozó), bizonyítékon alapuló, a tudományos ismereteket magas színvonalon átadó élethosszig tartó oktatásnak/továbbképzésnek. Az aktív betegellátásban tevékenykedő dolgozók és hallgatók egészségmegőrzésében, -fejlesztésében fontos szerepet játszik egyrészről a foglalkozás-egészségügyi szolgálat munkahelyi egészségnevelés tevékenysége, másrészről a munkavállalók, hallgatók egészségműveltsége. Az oltandók kedvező oltási magatartásának kialakítása és megerősítése érdekében alapvető a veszélyeztetett és veszélyeztető csoportba tartozás tudatosítása, a vakcinációs előnyök és a felelősségtudat hangsúlyozása, továbbá a soha nem oltottak érzelmi megközelítésű immunizációs érzékenyítése, meggyőzése. Az átoltottság fokozása érdekében kiemelendő az oltóorvosok és egészségügyi szakdolgozók preventív szemléletének formálása. Megvalósításához elengedhetetlen az oltóorvosoltandók és/vagy a foglalkozás-egészségügyi szolgálat-munkáltató között kialakított információs rendszer és helyesen megválasztott kommunikációs stratégia kialakítása és müködtetése.

Jelenleg is tartó epidemiológiai kutatásunk eredményeire alapozottan lehetőség nyílik a munkáltatók vakcinációs érdekeltségének, az oltóorvosok motiváltságának és az oltandók immunizációs motivációjának, végső soron az oltásban résztvevő valamennyi szereplő oltási tudatosságának fokozására. Ez újabb előrelépést jelenthet a hazai egészségügyi ellátásban a betegelégedettség és -biztonság kedvező irányú változásában. 
Anyagi támogatás

a közlemény megírása anyagi támogatással nem járt.

\section{Szerzői munkamegosztás:}

probléma felvetés, irodalmazás, hipotézisek kidolgozása: VT, BF, DKN; kérdöív összeállítása: VT, LA, MA, BF, DKN, PE; EvaSys on-line kérdőív szerkesztése, aggregált adatok print outjának elkészítése: HB, KCs; a vizsgálat lefolytatása, SPSS statisztikai elemzések, eredmények kiértékelése: VT, LA, MA, BF, DKN, PE; ábrák, táblázatok elkészítése, kézirat megszövegezése: VT.

Nyilatkozat

a cikk végleges változatát valamennyi szerző elolvasta és jóváhagyta.

Érdekeltségek:

a szerzőknek nincs érdekeltsége

\section{Irodalomjegyzék}

1. Iuliano AD, Roguski KM, Chang HH. et al. Estimates of global seasonal influenza-associated respiratory mortality: a modelling study. Lancet. 2018;391:1285-300.

DOI: https://doi.org/10.1016/S0140-6736(17)33293-2

2. Cassini A, Colzani E, Pini A, et al. Impact of infectious diseases on population health using incidencebased disability-adjusted life years (DALYs): results from the Burden of Communicable Diseases in Europe study, European Union and European Economic Area countries, 2009 to 2013. Euro Surveillance. 2018;23(16). DOI: https://doi.org/10.2807/1560-7917.ES.2018.23.16.17-00454

3. Ryan J, Zoellner Y, Gradl B, et al. Establishing the health and economic impact of influenza vaccination within the European Union 25 countries. Vaccine. 2006;24(47-48):6812-6822. DOI: https://doi.org/10.1016/j.vaccine.2006.07.042

4. Kassianos $G$, Blank $P$, Falup-Pecuriariu $O$, et al. Influenza vaccination: key factors for general practitioners in Europe Europe - a synthesis by European experts based on national guidelines and best practices in the United Kingdom and the Netherlands. Drugs in Context. 2016. 5:212293, DOI: https://doi.org/10.7573/dic.212293

5. Hulo S, Nuvoli A, Sobaszek A, et al. Knowledge and attitudes towards influenza vaccination of health care workers in emergency services. Vaccine. 2017;35:205-207.

DOI: https://doi.org/10.1016/j.vaccine.2016.11.086

6. Nicoll A, Ciancio BC, Lopez Chavarrias V, et al. Influenza-related deaths - available methods for estimating numbers and detecting patterns for seasonal and pandemic influenza in Europe. Euro Surveillance. 2012;17(18) DOI: https://doi.org/10.2807/ese.17.18.20162-en 
7. Council of the European Communities. Proposal for a Council Recommendation on Seasonal Influenza Vaccination 2009 [cited 2017 Nov 8].

http://ec.europa.eu/health/ph_threats/com/Influenza/docs/seasonflu_rec2009_en.pdf Elérve: 2018. 10. 04.

8. Országos Epidemiológiai Központ. Az ECDC kockázatértékelése a 2016-2017 évi influenzaszezonról. Epinfo. 2017;24(3):21-26.

9. European Centre for Disease Prevention and Control. Seasonal influenza vaccination in Europe. Vaccination recommendations and coverage rates in the EU Member States for eight influenza seasons: 2007-2008 to 2014-2015. Stockholm: 2017; ECDC.

10. World Health Organisation. Meeting of the Strategic Advisory Group of Expers on immunization, April 2012 - conclusions and recommendations. Weekly epidemiological record.2012;21(87):201-216. https://www.who.int/wer/2012/wer8721/en/

11. Council of the European Union. State of play on implementation of the Council Recommendation of 22 December 2009 on seasonal influenza vaccination (2009/1019/EU). 2014 [cited 2017 Nov 8]. http://ec.europa.eu/health/vaccination/docs/seasonflu_staffwd2014_en.pdf. Elérve: 2018. 11. 12.

12. World Health Organisation. WHO Regional Office for Europe recommendations in influenza. WHO. 2017;1-5.

13. European Centre for Disease Prevention and Control. Seasonal influenza vaccination and antiviral use in EU/EEA Member States - Overview of vaccine recommendations for 2017-2018 and vaccination coverage rates for 2015-2016 and 2016-2017 influenza seasons. Stockholm: 2018; ECDC.

14. Egészségügyi Minisztérium. 61/1999. (XII. 1.) EüM rendelet a biológiai tényezők hatásának kitett munkavállalók egészségének védelméről https://net.jogtar.hu/jr/gen/hjegy doc.cgi?docid=99900061.eum Elérve: 2019. 11. 10.

15. Emberi Erőforrások Minisztériuma. A Nemzeti Népegészségügyi Központ módszertani levele a 2019. évi védőoltásokról. Egészségügyi Közlöny. 2019;8:813-846.

16. Országos Epidemiológiai Központ. Influenza elleni védőoltások az Európai Unióban. Epinfo. 2016;23(42-43):522-529.

17. Carman WF, Elder AG, Wallace LA, et al. Effects of influenza vaccination of health-care workers on mortality of elderly people in long-term care: a randomised controlled trial. Lancet. 2000;355:93-97. DOI: https://doi.org/10.1016/S0140-6736(99)05190-9

18. Orosi P, Borbély Á, Szidor J, et al. Az influenza átoltottságot befolyásoló tényezők vizsgálata egészségügyi dolgozók körében a Debreceni Egyetem Orvos- és Egészségtudományi Centrumában. Orvosi Hetilap. 2012;53(3):505-513. https://doi.org/10.1556/OH.2012.29328 